\title{
Encantamento do rosto. Poses e retratos de cinema
}

\begin{abstract}
Ana Carolina de Moura Delfim Maciel $^{1}$
RESUMO: O presente artigo tem como objetivo caracterizar um conjunto de imagens fotográficas da atriz de cinema Eliane Lage (1928-) que atuou em Caiçara, Ângela, Sinhá Moça e Ravina produções da Companhia Cinematográfica Vera Cruz (1950-1954), e, no caso de Ravina, da Cinematográfica Brasil Filmes. A Companhia Cinematográfica Vera Cruz pretendeu ser um dos maiores empreendimentos cinematográficos do Brasil e, inserido nessa proposta, seu Departamento de Publicidade buscou estabelecer a atriz Eliane Lage como uma grande estrela, nos moldes de cinematografias hegemônicas. Acompanham-se, aqui, alguns retratos que, somados às informações publicadas na imprensa, tinham como intuito situar ao grande público quem era Eliane Lage, abordando aspectos da sua "biografia" com temas amplamente explorados, dentre eles sua origem abastada, a negação do estrelato, o despojamento, a paixão pelo marido e o gosto pela natureza. Dentre os retratos selecionados há um ensaio fotográfico do arquiteto Gregori Warcharchik; fotografias de divulgação dos estúdios; "instantâneos" feitos por fotógrafos da época; e fotografias que integram o acervo pessoal da atriz.

PalAVRAS-ChaVE: Cinema. Atrizes. Eliane Lage. Companhia Cinematográfica Vera Cruz. Cinematográfica Brasil Filmes.
\end{abstract}

ABSTRACT: The purpose of this article is to describe a set of photographs of Eliane Lage (1928-), a movie actress featured in Caiçara, Ângela, Sinhá Moça and Ravina - the first three produced by Companhia Cinematográfica Vera Cruz (1950-1954), and the fourth by Cinematográfica Brasil Filmes. Companhia Cinematográfica Vera Cruz aspired to be one of the largest film producers in Brazil and, accordingly, its Advertising Department set out to establish Eliane Lage as a great movie star, like those in the world's dominant movie industries. This paper brings to light some photographs which, coupled with information published in the press, were intended to tell the public at large who Eliane Lage was by exploring extensively certain aspects of her "biography", such as her privileged background, her denial of stardom, her detachment, her passion for her husband, and her love of nature. The picture selection includes: a photo essay by the architect Gregori Warcharchik; studio marketing photographs; snapshots taken by photographers at the time; and pictures that are part of the actress's personal collection.

KEYWORDS: Cinema. Actresses. Eliane Lage. Companhia Cinematográfica Vera Cruz. Cinematográfica Brasil Filmes.

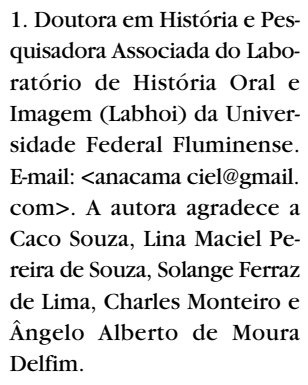
Delfim. 
2. Ver Siegfried Kracauer (2009).

3. Cf. Edgar Morin (1997, p. 15-16).

4. Ver Jacques Aumont (1998).

5. Ibidem.

6. Idem, p. 13 .

7. Idem, p. 19.

8. Cf. Tom Gunning (2001,

p. 43)

9. Ibidem.
Assim é como parece uma Diva do cinema. Ela tem 24 anos e está na capa de uma revista ilustrada, diante do Hotel Excelsior do Lido. Estamos em setembro. Se alguém olhasse através de uma lupa veria, na reticula, os milhões de minúsculos grãos que formam a diva, as ondas e o hotel. Certamente a imagem não pretende mostrar uma reticula de grãos, mas a diva de carne e osso no Lido [...]. Todos a reconhecem encantados, pois já viram o original na tela de cinema. ${ }^{2}$

Siegfried Kracaver

Todo o real apercebido passa, portanto, pela forma de imagem. Depois, renasce em forma de recordação, isto é, como imagem de imagem. Ora, o cinema, como toda figuração (pintura, desenhol é uma imagem de imagem, mas, como a fotografia, é uma imagem da imagem perceptiva e, melhor do que a fotografia, é uma imagem animada, quer dizer, viva. É enquanto representação de representação viva que o cinema nos convida a reflectir sobre o imaginário da realidade e sobre a realidade do imaginário ${ }^{3}$

Edgar Morin

Ao longo dos séculos representações de figuras femininas inspiraram manifestações artísticas e, nesse percurso, o rosto foi o maior depositário do encantamento da beleza. Um rosto atraente ou significativo - é para onde se dirige o olhar e de onde o mesmo emana. $\bigcirc$ rosto detém traços de identidade, verossimilhança e exterioriza estados d'alma. O rosto fascina e é uma espécie de janela da alma, expressão máxima da identidade do gênero humano. A relação intensa entre rosto e cinema inspirou o teórico Jacques Aumont ${ }^{4}$ a dedicar o livro Du visage au cinéma inteiramente ao assunto 5 :

O que antes poderia provocar as lágrimas de uma jovem, um fluxo de lágrimas irreprimíveis, desamparadas, quase voluptuosas? Evidentemente a contemplação de um rosto, e nada mais: um rosto em grande primeiro plano, cortado monstruosamente de seu corpo, terrivelmente sofredor, torturado, solitário sobre um fundo branco que ressalta seu desamparo ${ }^{6}$.

Analisando tal poder de representação o autor considera que o rosto é a "parte nobre do indivíduo" e detém forte significado no universo das manifestações artísticas, pois "as representações servem apenas para representar o rosto do homem" 7 . Com o advento da cultura de massas, tal fascínio atingiu uma amplitude jamais vivenciada, sendo a fotografia precursora nesse processo de representações. Tom Gunning considera que os registros fotográficos possibilitaram uma abolição de "barreiras do espaço", transformando seu conteúdo em "simulacros portáteis" 8 : "O próprio corpo pareceu ter sido abolido, tornado imaterial, por meio da fantasmagoria da fotografia fixa e em movimento"9. 
Tal poder "fantasmagórico" das imagens foi impulsionado pela sétima arte, quando imagens e fragmentos do rosto puderam ser contemplados em dimensões inéditas. A câmera cinematográfica, por meio do primeiro plano e do close up, monumentalizou o rosto em proporções até então inimagináveis, e esses seres "hiper reais", segundo designou Edgar Morin 10, resultantes de "monstruosas ampliações", segundo Jacques Aumont ${ }^{1}$, são habitantes das telas e suscitaram nos espectadores o fenômeno de adoração que impulsionou o star system.

Contemporâneo à eclosão do star system, o escritor e crítico André Malraux publicou Esquisse d'une psychologie du cinéma ${ }^{12}$, onde analisou o poder mítico das atrizes de cinema: "uma estrela não é de forma alguma uma atriz que faz cinema. É uma pessoa capaz de um mínimo de talento dramático, cujo rosto exprime, simboliza, encarna um instinto coletivo" ${ }^{13}$. Malraux atribuía ao primeiro plano e às imensas amplitudes do close up a possibilidade de que os espectadores vislumbrassem os atores de cinema como jamais puderam vislumbrar aqueles de teatro. $O$ cinema explorou exaustivamente o forte poder sugestivo do primeiro plano e, sobre tal fenômeno, o cineasta Serguei Eisenstein afirmou que considerava uma barata filmada em primeiro plano mais aterrorizante que uma "manada de elefantes" registrada em plano geral ${ }^{14}$.

Embora registro estático - sem o apelo das imagens em movimento -, as fotografias de atrizes publicadas pela imprensa movimentavam o mercado editorial e reiteravam os signos difundidos pelo cinema ${ }^{15}$. Entre as décadas de 1920 e 1930, Siegfried Kracaver - em suas colunas semanais no Frankfurter Zeitung - analisou o teor desse gênero de revistas:

A intenção das revistas ilustradas é reproduzir completamente o mundo acessível ao aparelho fotográfico; registram espacialmente o clichê das pessoas, situações e acontecimentos em todas as perspectivas possíveis [...]. Nunca houve uma época tão bem informada sobre si mesma, se ser bem informado significa possuir uma imagem das coisas iguais a elas no sentido fotográfico ${ }^{16}$.

No Brasil, o vasto material fotográfico produzido pelo Departamento de Publicidade da Companhia Cinematográfica Vera Cruz ${ }^{17}$ alimentava as revistas ilustradas e também a imaginação de seus leitores. Assim, entre 1949 e 1954, os estúdios implantaram um sistema de divulgação nos moldes do star system hollywoodiano.

As fotografias de Eliane Lage ${ }^{18}$ que doravante vou abordar foram publicadas em suportes efêmeros e concebidas para serem vistas de forma fragmentada. Tendo como principal suporte a imprensa especializada, tais fotografias tinham como meta alavancar uma proposta de cinema industrial ${ }^{19}$. Tratava-se de um esforço em estabelecer um sistema estrelar para um publico acostumado a cultuar estrelas norte-americanas, concorrência desleal, visto tratarse de um "inimigo" poderoso, "rico" e que reinava soberano. Ao "star system" brasileiro restaria apenas um papel periférico.

A Vera Cruz pretendia produzir filmes em escala industrial, e seu Departamento de Publicidade - um dos pilares mais bem estruturados dos estúdios
10. Cf. Edgar Morin (2000, p. 16).

11. Ver Jacques Aumont (1998).

12. Ver André Malraux (1946).

13. Ibidem; tradução livre da autora.

14. Serguei Eisenstein apud Jacques Aumont (1992, p. 99).

15. No campo das fotografias de cinema, a Biblioteque du Film (Paris) elaborou uma descrição que visa cartacterizar tais registros; selecionei alguns que considero interessante reproduzir: "A fotografia de set: ilustra precisamente o filme e compreende cenas eventualmente cortadas da montagem. A fotografia de cena assemelha-se muito proximamente ao que é visível na tela. A fotografia de promoção: pode ser retratos de atores posando, caracterizados ou não, inicialmente para promover o filme, fotografias com elementos de publicidade associados à imagem, ou ainda à representação de uma promoção pública com um cartaz. O fotograma: A imagem é tomada diretamente da película do filme." <http://www.bifi.fr/ public/index_page.php?OBJ ID=Tzo0OiJEYXRhIjoxOntz OjY6Im9ial9pZCI7aTo1Mjt9 \#photos.>. Tradução livre. Acesso em 30/04/2010.

16. A afirmação de Kracauer é de espantosa atualidade, considerando o advento da internet e das câmeras digitais, que instauraram uma busca incessante por registros fotográficos e por sua divulgação quase em tempo real.

17. A fundação da Companhia Cinematográfica Vera Cruz, em 1949, foi iniciativa de dois empresários, o italiano Franco Zampari (Nápoles, 1898 - São Paulo, 1966) e o brasileiro Francisco Matarazzo Sobrinho, conhecido por Cicillo (São Paulo, 1898 - 
1977). Durante alguns anos, o parque cinematográfico da Vera Cruz foi considerado como o "maior da América do Sul", e a imprensa - divulgando matérias e entrevistas tendo a "indústria de cinema" como tema ou como meta - em muito contribuiu para corroborar o clima de deslumbre.Um personagem chave desse processo de industrialização foi o produtor e cineasta Alberto de Almeida Cavalcanti (Rio de Janeiro, 1897- Paris, 1982), que iniciou carreira artística em Paris como cenógrafo de Marcel L'Herbier e Louis Delluc. Ao longo de sua trajetória, Cavalcanti acumulou diversas funções no cinema: engenheiro de som, roteirista, montador, produtor e diretor. Ele veio ao Brasil em 1949, para proferir uma série de palestras no Automóvel Clube, na Federação das Indústrias do Comércio e da Lavoura, e no Centro de Estudos Cinematográficos do Museu de Arte de São Paulo. Nesse momento lhe foi feito o convite para assumir o cargo de produtor geral da Companhia Cinematográfica Vera Cruz. Cavalcanti assumiu em janeiro de 1950 e apenas um ano depois, deixou o cargo. Possíveis motivos do rompimento foram alvo de especulação da imprensa: incompatibilidades com Franco Zampari, protesto contra a entrada do produtor Fernando de Barros, altos custos empatados em suas produções; o fato é que esse foi o primeiro grande fracasso da empresa, prenunciando o início de seu precoce declínio.

18. Eliane Margaret Elisabet Lage nasceu em Paris no ano de 1928 e logo em seguida veio para o Brasil. Após a separação dos pais e o retorno de sua mãe à Europa, ela foi morar numa Ilha situada no litoral carioca, pertencente ao seu bisavô paterno - Antônio Martins Lage, comumente conhecido como Tonico um milionário proprietário de estaleiros, de companhia de
- fornecia releases e stills para cerca de seiscentos veículos de comunicação, atingindo os mais longínquos pontos do Brasil. Sendo assim, Eliane Lage foi eleita como o "carro chefe" do elenco feminino e era constantemente comparada aos grandes ícones da cinematografia internacional: "Eliane é sempre bela, sempre aquela figura exótica de mulher, uma mistura de Greta Garbo e Ingrid Bergman"20". É interessante tal cotejo, pois Greta Garbo e Ingrid Bergman não são propriamente semelhantes, o que nos faz supor que, nesse gênero de comparação, não estava em jogo uma semelhança física, mas o poder que cada uma delas exercia no imaginário da sua época.

Nos dias atuais, ainda persistem paralelismos entre atrizes "icones". Recentemente, o diretor de teatro Robert Wilson comparou duas atrizes igualmente diferentes e de épocas distintas: Isabelle Hupert e Greta Garbo ${ }^{21}$. Wilson - que vê grande semelhança entre as duas estrelas - diz que, ao relatar sua impressão a Hupert, ela teria afirmado que ele era "a única pessoa" capaz de notar tal similitude. Não obstante, Wilson fez um retrato dela imitando Greta Garbo e concluiu que para ele: "ela [Hupert], de certo modo, foi sempre Greta Garbo"22. Esse tipo de comparação remete a uma necessidade de manter vivos mitos de outrora, perpetuando-os em personagens contemporâneos. Em comparações dessa ordem, o que está em jogo é o poder simbólico e, também, o significado de determinada atriz em seu tempo, e menos, uma semelhança física.

Primeiras imagens

Um dos ícones da arquitetura moderna no Brasil, Gregori Warchavchik ${ }^{23}$ tinha a fotografia como hobby e dedicou-se principalmente aos retratos ${ }^{24}$. No final dos anos 1940, ele fez uma série de registros de Eliane Lage, que desempenharam papel fundamental para alavancar sua carreira. Tais imagens - uma delas reproduzida na Figura 1 - foram mostradas ao produtor Alberto Cavalcanti como prova do potencial fotogênico da futura atriz. Não encontrei nenhum registro da data em que tais fotografias foram tiradas, mas, provalmente, deve ter sido próxima ao referido almoço na casa de Yolanda Penteado, pois nessa ocasião, em 1949, Eliane Lage regressava de um período de férias na Fazenda Empyreo e no Guarujá (onde as fotografias foram realizadas).

Sobre as fotografias, Eliane diz:

São fotos que o Warchavchik tirou quando eu estava no Guarujá e... e foi quase como que uma prova de que eu era fotogênica, enfim. Então foi graças a essas fotos que eu entrei pro, fiz o teste [para o papel de Marina no filme Caiçara], graças a elas ${ }^{25}$.

A ambiência do cenário remete a um espaço doméstico, provavelmente uma sala de estar, onde Eliane posa para o fotógrafo tendo como pano de fundo uma janela com cortinas florais. Ela surge em close, completamente sem maquiagem, cabelos soltos, trajando vestido escuro, cujo amplo decote evidencia 


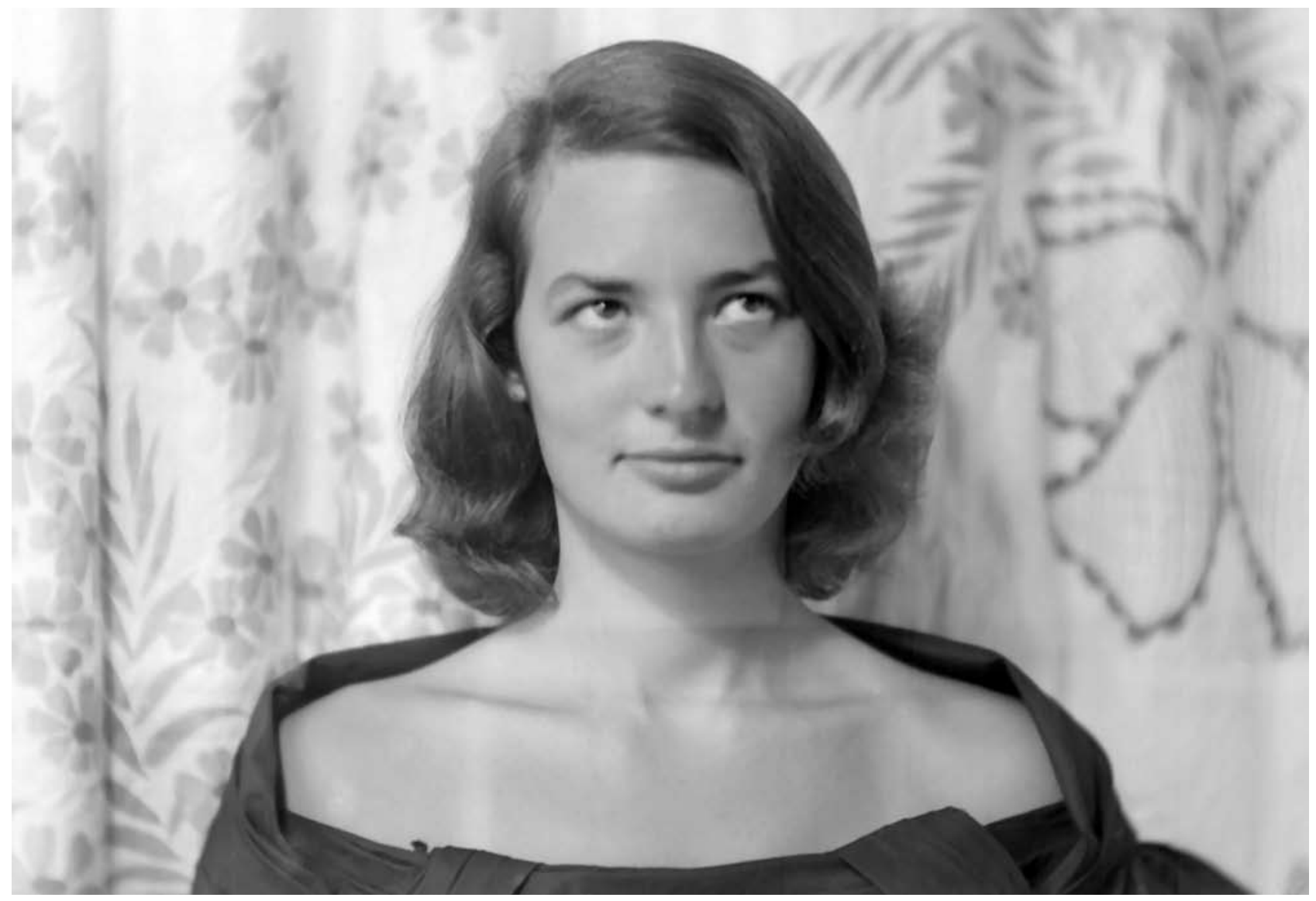

Figura 1 - Gregori Warchavchik. Eliane Lage. [1949?]. Acervo da família Warchavchik, São Paulo. Fonte: AQUINO, Paulo Mauro Meyer (Org.) Gregori Warchavchik - Acervo fotográfico 1. São Paulo, 2005.

o bronzeado. Seu campo de visão não confronta a câmera, voltando-se para o canto superior do quadro. $\bigcirc$ conjunto de fotografias feitas por Warchavchik iria prenunciar elementos recorrentes em imagens posteriores de Eliane Lage, já como atriz de cinema (Figura 2) 26

Em 1950, Eliane Lage estreia em sua carreira cinematográfica, em Caiçara, como a protagonista "Marina", uma jovem que vai morar numa ilha após se casar com um rude pescador. Nas fotografias de divulgação do filme, ela aparece com vestidos de algodão, xales, cabelos soltos e sem maquiagem. A estrela inaugural da Vera Cruz era representada de forma naturalista, sugerindo a inspiração do diretor do filme - o italiano Adolfo Celi - em atrizes do cinema neorrealista. Eram frequentes, na imprensa, comparações entre Stromboli e Caiçara; e, com o lançamento de Caiçara, instaurou-se a tendência de comparar Eliane Lage a Ingrid Bergman.

Uma das primeiras imagens de Eliane Lage na imprensa brasileira talvez a primeira - foi publicada no libreto do Teatro Brasileiro de Comédia: navegação marítima e de minas de carvão. Após uma breve temporada vivendo na Europa em companhia da mãe, em 1949 ela decide voltar para o Brasil. Nas férias desse mesmo ano, ela passa alguns dias em São Paulo, quando conhece o diretor argentino Tom Payne, num almoço oferecido por Yolanda Penteado para recepcionar os técnicos que Alberto Cavalcanti havia trazido da Europa para trabalhar na Companhia Cinematográfica Vera Cruz. Tom Payne, futuro marido de Eliane, em muito contribuiu para sua decisão de iniciar carreira como atriz em Caiçara, primeiro filme da nascente Companhia. 


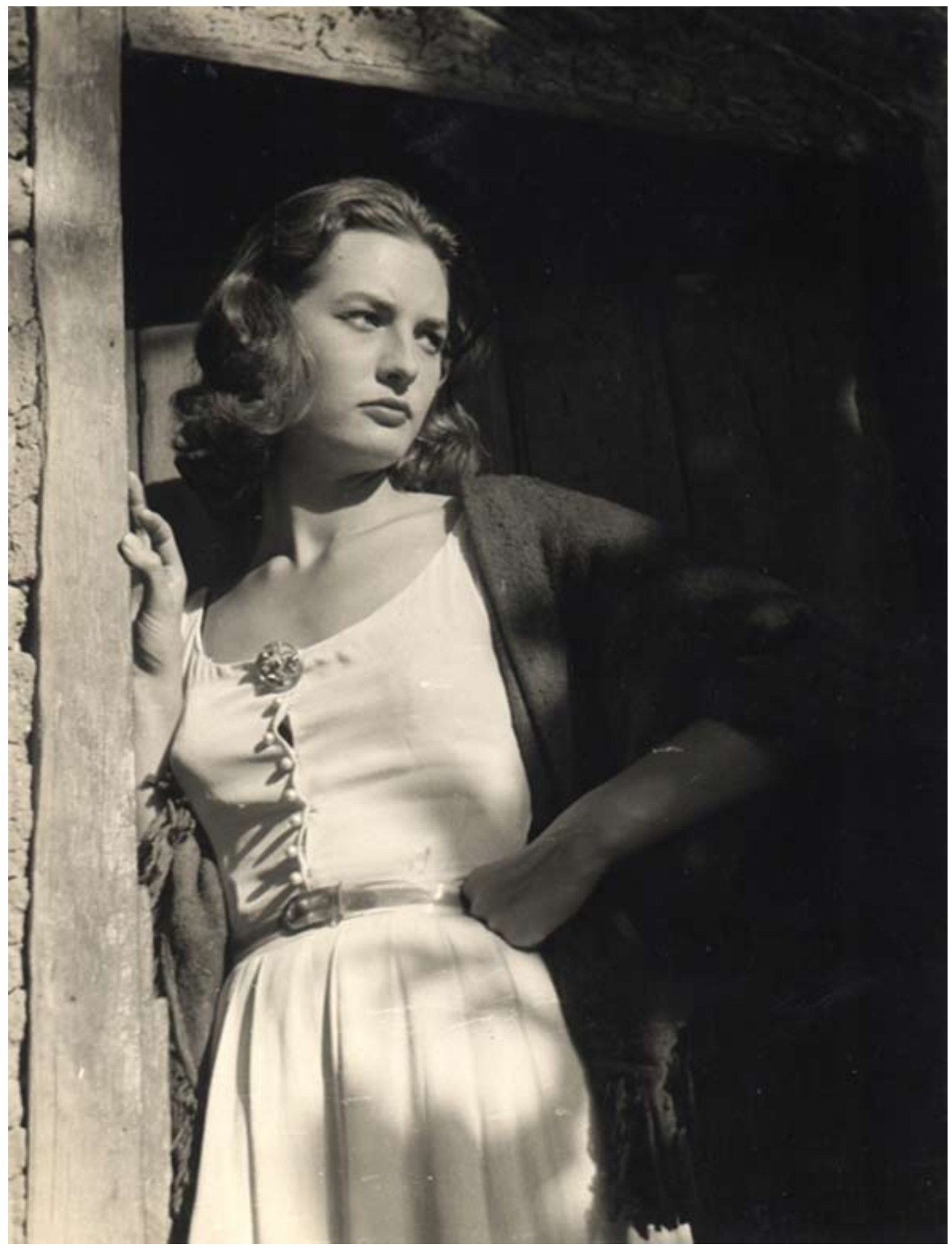

Figura 2 - Fotógrafo não identificado. Eliane Lage como Marina. 1950. Acervo da Biblioteca Jenny Klabin Segall, Museu Lasar Segall / IBRAM / MinC, São Paulo. 
trata-se de uma pequena fotografia em preto e branco, com chiaroscuro bem contrastado, onde o fundo preto contrasta com o tom claro da sua pele (Figura 3). Eliane Lage posiciona-se num perfil parcial, com a franja pendendo sobre um dos olhos, o olhar deslocado para o canto superior do quadro e com a cabeça ligeiramente tombada; ela traja vestido de cor escura, cujo decote deixa parte do colo à mostra ${ }^{27}$.

A fotografia é resultante de um "ensaio de fotogenia", comumente realizado em estúdios cinematográficos para conseguir delimitar os "melhores ângulos" das estrelas e disfarçar possíveis imperfeições. Uma vez estabelecida a fotogenia, pode-se buscar a iluminação e movimentação de câmera ideais, visando a valorizar os traços do rosto. A fotogenia, segundo definição de Jacques Aumont, serve para designar objetos que "produzem" - na verdade, refletem - luz suficiente para impressionar a placa fotográfica. Sendo assim, um rosto é considerado "fotogênico" quando "sai" bem na fotografia e surge de maneira "inesperada, interessante, poética e encantadora", segundo palavras de Aumont ${ }^{28}$.

Em outra fotografia - de composição bastante semelhante àquela do libreto do TBC e que provavelmente integrava a mesma série -,um quadrado desenhado a caneta delimita, emoldura, reenquadra o ângulo que se pretendia ressaltar (Figura 4). Esses primeiros retratos de Eliane remetem às estrelas etéreas, a uma aura de magia e, também, de inacessibilidade. $\bigcirc$ olhar deslocado para fora do quadro evita confrontamento direto com o observador, denotando passividade e discreta sensualidade. Em tais registros, ela aparenta usar pouca (ou nenhuma) maquiagem, surgindo sempre com cabelos soltos e portando discreto figurino.

Alguns elementos que compõem e articulam tais fotografias, tais como o privilégio do rosto em detrimento a outras partes do corpo; uma valorização da textura da pele; o recorrente deslocamento do olhar; o ângulo de enquadramento; um forte contraste claro escuro e amplos decotes podem ser encontrados em fotografias de Greta Garbo, estrela pioneira a quem - não por acaso - Eliane Lage foi constantemente comparada. É possível considerar que fotografias de estrelas já consagradas e que povoavam o imaginário da época no Brasil - e também no mundo-tenham servido de inspiração para composições que conferiam forma à estrela estreante da Vera Cruz.

Se compararmos a fotografia de Eliane Lage que foi publicada no libreto do Teatro Brasileiro de Comédia com imagens de Greta Garbo é possível constatar semelhanças de posicionamento, de figurino lque serve apenas para emoldurar o colo), de deslocamento do olhar para fora do quadro (para cima ou para baixol, de enquadramento do rosto e de forte contraste claro escuro 29 . Não há como afirmar que o fotógrafo que efetuou tais registros de Eliane Lage teve contato com as fotografias de Garbo, mas o fato é que, desde os primórdios do século XX, revistas brasileiras de cinema, como Cinelândia e A Scena Muda, reproduziam fotografias de atrizes do cinema internacional, algo que possivelmente deve ter influenciado os fotógrafos da Companhia.

Segundo Edgar Morin, privilegiar o rosto remete a uma tendência instaurada pelo cinema mudo, quando o corpo humano foi truncado eliminando-
19. Não é meu intuito, neste artigo, aprofundar uma análise formal desse material visual. Minha intenção principal é apresentá-lo, para possibilitar que se acompanhe como foi concebida a estruturação, por meio do suporte fotográfico, de uma imagem de Eliane Lage além daquela projetada no écran cinematográfico. Para tal, selecionei alguns retratos que considero significativos.

20. Cf. Cinelândia, $\mathrm{n}^{\circ} 248$, ano XI, março (1963, p. 60).

21. Ver Antonio Gonçalves Filho (2008).

22. Ibidem.

23. Gregori Warchavchik (Odessa, 1896 - São Paulo, 1972).

24. Sobre a atividade de Warchavchik como fotógrafo, diz Rubens Fernandes Jr: "É notável sua participação na década de 1940 das atividades promovida pelo Foto Cine Clube Bandeirante mas, curiosamente, sua fotografia nada tem a ver com a arquitetura, pois privilegia quase sempre o retrato". Disponível em: <http://www.iconica.com.br/?tag=gregori-warchavchik>. Acesso 27 abr. 2010.

25. Eliane Lage, em depoimento à autora, fev. 2001.

26. Nos estúdios da Vera Cruz havia um setor de registros fotográficos, chefiado pelo fotógrafo Júlio e que contava com dois profissionais: Valentim e Luiz, dos quais infelizmente não consegui descobrir maiores informações. Infelizmente as fotografias de divulgação não apresentam identificação de autoria.

27. Encontrei, no acervo Marcelo Del Cima, uma fotografia idêntica à publicada no libreto do TBC. No canto inferior da imagem, no lado direito, é possível vislumbrar 


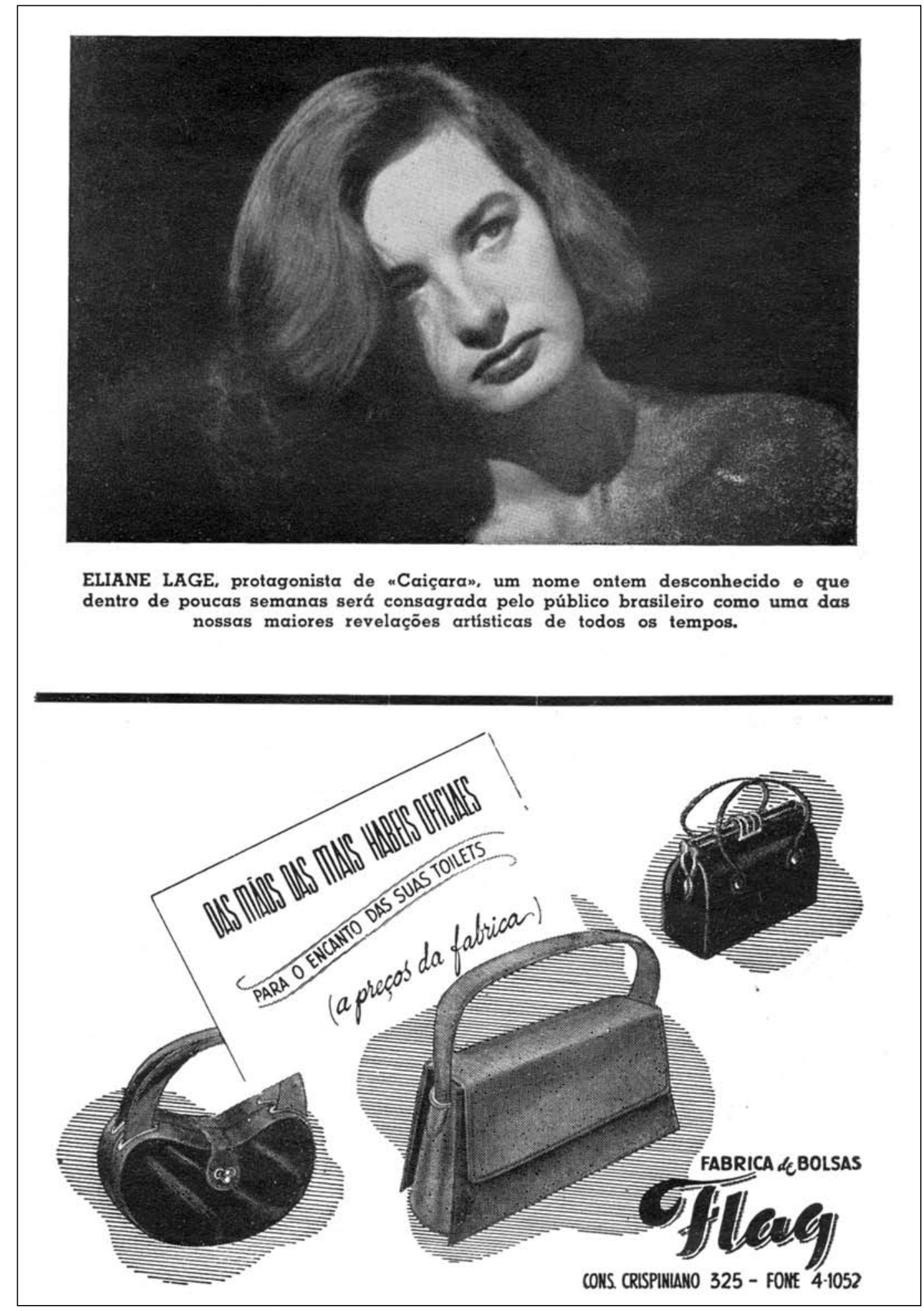

Figura 3 - Fotógrafo não identificado. Eliane Lage, no libreto do Teatro Brasileiro de Comédia. 1950, n. 19. Acervo pessoal de Hélio Eichbauer. 


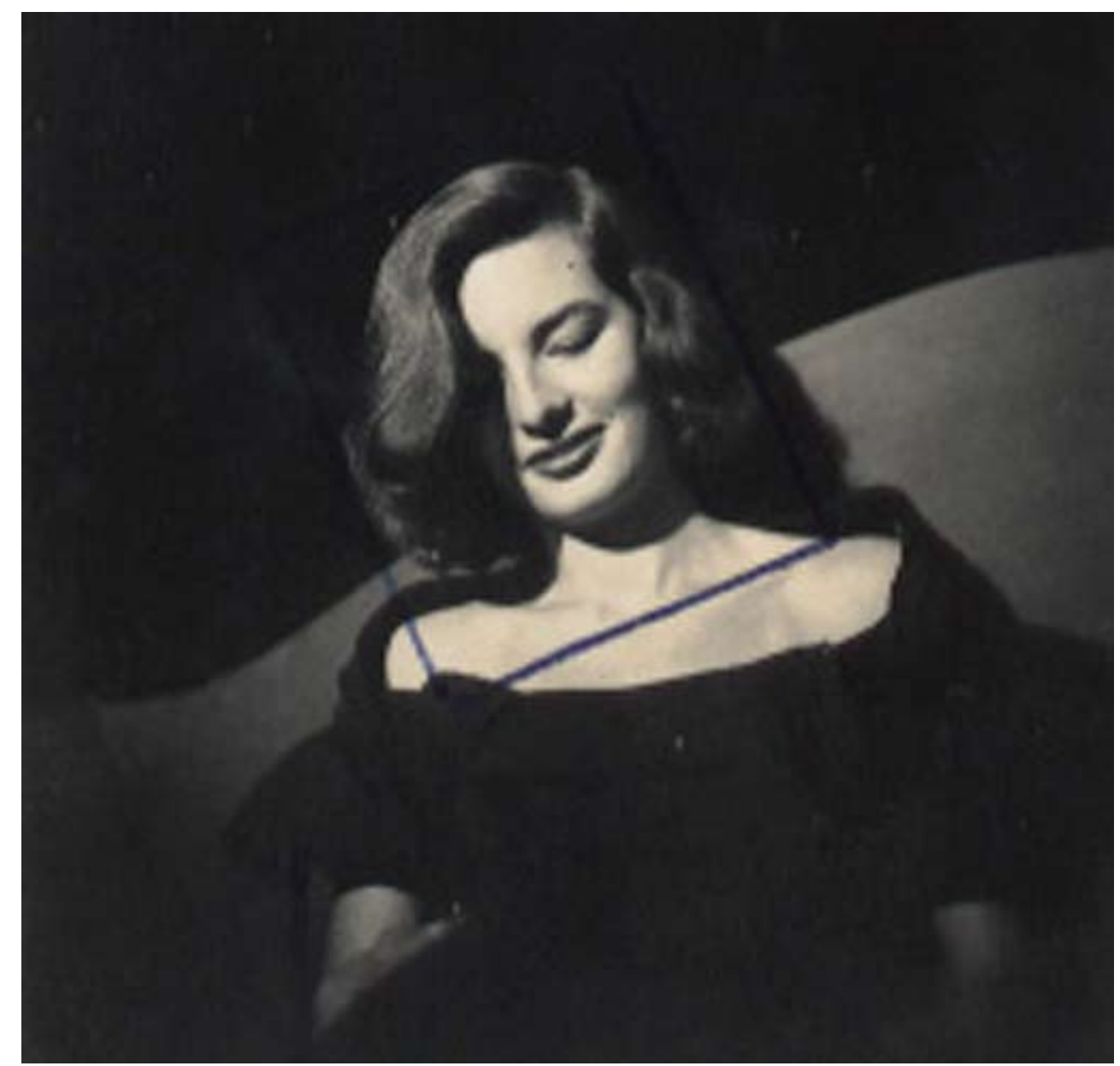

Figura 4 - Fotógrafo não identificado. Eliane Lage, anos 1950. Acervo pessoal de Eliane Lage.

se do ângulo de registro "os membros inferiores", possibilitando assim uma "glorificação" do rosto humano, em detrimento ao restante do corpo. Nesses primórdios, os registros fotográficos de estrelas incutiam-lhes uma aura deificada, e elas assumiam a postura de objeto de culto, inacessíveis e intransponíveis ${ }^{30}$.

Roland Barthes também refletiu sobre o poder sugestivo do rosto e, no ensaio O rosto de Garbo, publicado entre 1954-1956, dedicou-se exclusivamente ao assunto. Para Barthes a atriz sueca pertencia a uma fase do cinema cujo "enfoque no rosto humano deixava as multidões profundamente perturbadas" 31 , utilizando-se da expressão "rosto-objeto" para definir a imagem preponderante da atriz. Ao analisar o filme Rainha Cristina, diz o autor:

a pintura de Garbo tem a espessura nervosa de uma máscara; não é um rosto pintado, mas sim um rosto engessado, defendido pela superfície da cor e não por suas linhas [...]. Mesmo em sua extrema beleza, este rosto, mais do que desenhado, é esculpido no liso e no friável, isto é, simultaneamente perfeito e efêmero ${ }^{32}$.

uma assinatura que, me parece, seja "Fred".

28. Cf. Jacques Aumont e Michel Marie (2007, p. 136).

29. Ver imagens de Greta Garbo disponíveis em <http:// www.doctormacro.com/Images/Garbo,\%20Greta/Annex/ Annex\%20-\%20Garbo,\%20 Greta_03.jpg > e <http://upload.wikimedia.org/wikipedia/ commons/5/52/Greta_Gar bo_1924_2.jpg>

30. Cf. Edgar Morin (1991, p. 166).

31. Cf. Roland Barthes (1993, p. 47-48). 
32. Ibidem.

33. Cf. Edgar Morin (1997, p. 54).

34. Tico-Tico no Fubá (CELI 1952).

35. É Proibido Beijar (1953-1954).

36. Cf. Cinelândia (1953a, p. 46).

37. Ver Cinelândia (1953b, p. 23)

38. Não me detenho na trajetória das atrizes de teatro nos anos 1950. Para tal, sugiro a leitura de Heloisa Pontes ([n. p.]).
Inegavelmente o cinema ampliou e carregou de sentido as funções narrativas e estéticas do rosto. Em linhas gerais, as fotografias de atrizes serviam para divulgar filmes, desempenhando a função de levar o publico ao cinema, e poderiam "materializar" estrelas, ao imprimir em papel imagens fugidias do écran cinematográfico, ou simplesmente ilustrar reportagens biográficas, conferindo uma trajetória às estrelas nascentes ou reiterando estrelas já consagradas. Adquirindo status próprio em relação aos filmes, a fotografia - segundo definição de Edgar Morin - apresenta um suporte material (em papel ou cartão), enquanto a imagem projetada na tela é "desmaterializada", "impalpável" e "fugaz"33. Assim, as revistas conseguiam materializar estrelas e torná-las mais acessíveis, democratizando (e, de certa forma, perpetuando) uma imagem que, finda cada sessão de cinema, desvanecia-se.

Imagens em revista

Embora em menores proporções, visło que o cinema brasileiro enfrentava dificuldades para constituir-se como indústria, a imprensa brasileira teve papel fundamental na gestação da estrela Eliane Lage. Analisando as publicações da época, é possível perceber os elementos que lhe conferiram forma. Em capas de revista, em flagrantes ou em fotografias de divulgação, suas imagens surgem associadas a uma produção cinematográfica que al mejava atingir escala industrial. A arriz foi a primeira protagonista da Vera Cruz, mas não a única; Tônia Carrero e Marisa Prado também estrelaram filmes lá, mas Eliane Lage correspondia a um anseio daquilo que os estúdios - sob a batuta do produtor Alberto Cavalcanti pretendiam divulgar como uma sendo uma star: um belo rosto, cabelos ao natural, figurino despojado (na linha das estrelas do neorrealismo italiano).

A atriz Tônia Carrero, outra estrela da Vera Cruz, atuou em Tico-Tico no Fubáa ${ }^{34}$, Apassionata e É Proibido Beijar ${ }^{35}$. Contrariamente ao comportamento discreto de Eliane Lage, Tônia era uma atriz glamour, presença constante em préestreias, coquetéis e eventos sociais, e destacada pela imprensa por possuir "plena consciência de sua posição de grande estrela" 36 . Sua vida pessoal fornecia "bons ingredientes" para a imprensa: a separação do marido Carlos Thiré, o filho Cecil, o romance com o diretor Adolfo Celi, e sua beleza "deslumbrante" deliciavam cronistas de plantão ${ }^{37}$. Atriz de cinema e teatro, ela trabalhou no Teatro Brasileiro de Comédia (TBC) e, em seguida, logo após o fracasso da Vera Cruz, foi dona da própria companhia, denominada Tônia-Celi-Autran, cujas produções atravessavam o país de norte a sul38.

Como contrapartida à Eliane Lage - que sistematicamente negava sua "vocação artística" - Tônia (bem como outras atrizes do período) situava na infância o desejo de atuar:

O momento sério da história foi quando ela [Tônia Carrero], ainda um tanto longe da adolescência, pediu que the reservassem um dos aposentos do domicilio doméstico para fazer o 
'seu teatro'. Então, aquela mania de falar sozinha, declamando papéis de personagens que ela mesma interpretava, e aquele jeitinho que demonstrava de dirigir as suas amiguinhas em espetáculos improvisados - não era apenas brincadeira de criança ? $^{39}$.

Na plêiade de atrizes da Companhia, havia lugar para a fábula de Cinderela, papel que coube a Marisa Prado, nome artístico de Olga Costenaro. Funcionária dos estúdios Vera Cruz, ela era qualificada pela imprensa como sendo a "caipirinha que virou estrela"40, "descoberta" nos estúdios, por Alberto Cavalcanti, que a transformou em "estrela da noite para o dia"4l. José Luiz Francunha, produtor da Vera Cruz, conta o que veio a saber sobre esta "descoberta":

Ela era operária. A Marisa, aconteceu o seguinte, ela era louca por cinema [...]. Então a Marisa Prado foi bater lá na Vera Cruz querendo emprego. Puseram ela na sala de montagem, como assistente de montagem, colando filme, colava o negativo, coisa assim. E começaram a fazer testes para o Terra é Sempre Terra, fazendo testes, testes, testes, e ela via, quando passava na moviola, ela via os testes, o resultado, e o comentário do Cavalcanti "e essa atriz, olha que horror; olha, tudo errado, ela faz isso assim, não sorri direito, não sei o que, não sei o quê". A Marisa era muito inteligente, então ela começou a guardar tudo aquilo. Até que um dia disseram "pôxa mas não tem ninguém nessa terra, não tem uma atriz, olha que porcaria". E ela disse: "bom, olha aqui uma atriz. Eu estou à disposição, vocês não me vêem". Aí o Abílio, ou o Cavalcanti, eu não me lembro qual dos dois - porque nessa época eu não estava na Vera Cruz, eles me contavam - eu sei que "já para a sala de montagem". Ela foi lá, se vestiu, fez um teste perfeito, e ela pegou o papel. Aí fizeram uma onda danada, a Cinderela do cinema brasileiro. "142.

No caso específico de Eliane Lage, o fato de descender de uma "família tradicional" - muito embora o império Lage começasse a ruir no pós-guerra - alimentava farto anedotário publicado sobre a atriz. A revista Foco, em julho de 1951 14, traz na capa sua fotografia acompanhada de um pequeno texto de apresentação, em que faz menção às suas origens familiares: "Eliane Lage é carioca, filha de uma das mais importantes famílias do Rio de Janeiro"44. Já A Cena Muda, tecendo algumas considerações sobre atrizes brasileiras, diz que Tônia Carrero "é muito bonita, muito inteligente"; em seguida, ao se referir a Eliane Lage, não faz nenhum elogio propriamente à sua beleza, mas à sua condição social, pois a atriz teria "muitos milhões em seu pé de meia"45. Em outra edição de A Cena Muda, seu status social é novamente abordado: "Eliane descende de grandes burgueses, mas não é granfinizada, felizmente" 46 . A imprensa teve papel fundamental na gestação da estrela Eliane Lage e - analisando as publicações da época - é possível perceber os elementos que lhe conferem forma.

Seus retratos podiam ser resultantes de ensaios sem nenhuma associação ao material de divulgação da Companhia; desvinculadas da proposta estética dos estúdios, as figuras 5 e 6 constituem um bom exemplo disso. A capa de $A$ Cena Muda caracteriza-se pela luz chapada e sem dramaticidade; na intenção de situar o espaço, uma grade emoldura o quadro e, por detrás dela, surge Eliane Lage. Diversamente das fotografias feitas pela Vera Cruz, há nesse registro um
39. Cf. Cinelândia (1954b, p. 34)

40. Cf. Cinelândia (1954a, p. 34).

41. Cf. de autor anônimo (1950).

42. José Luiz Francunha, depoimento à autora, em 27 abr. 2006

43. Cf. CAPA (1951)

44. Este texto de apresentação diz que Eliane Lage se interessava por teatro e que na França, frequentou o curso de Jean Louis Barrault; sabemos que Tônia Carrero frequentou tal curso, mas não foi o caso de Eliane Lage. Talvez tenha sido alguma confusão do repórter ou, quem sabe, uma "licença poética", para conferir mais legitimidade aos anos antecedentes do cinema.

45. Cf. A Cena Muda (1952, p. 15)

46. Cf. A Cena Muda (1951, p. 32) 


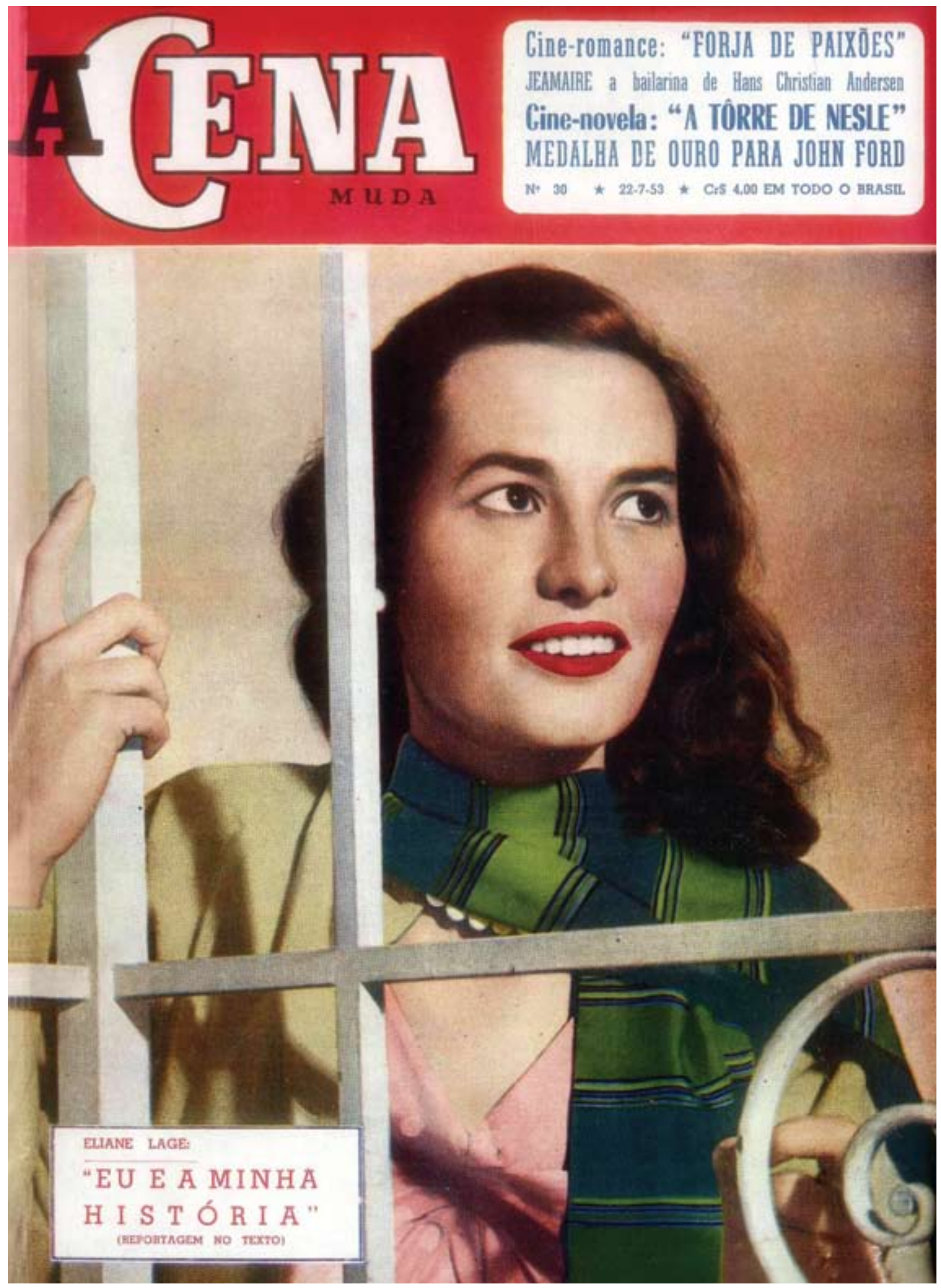

Figura 5 - Fotógrafo não identificado. Eliane Lage. A Cena Muda, 1953. Acervo da Biblioteca Jenny Klabin Segall, Museu Lasar Segall / IBRAM / MinC, São Paulo. 


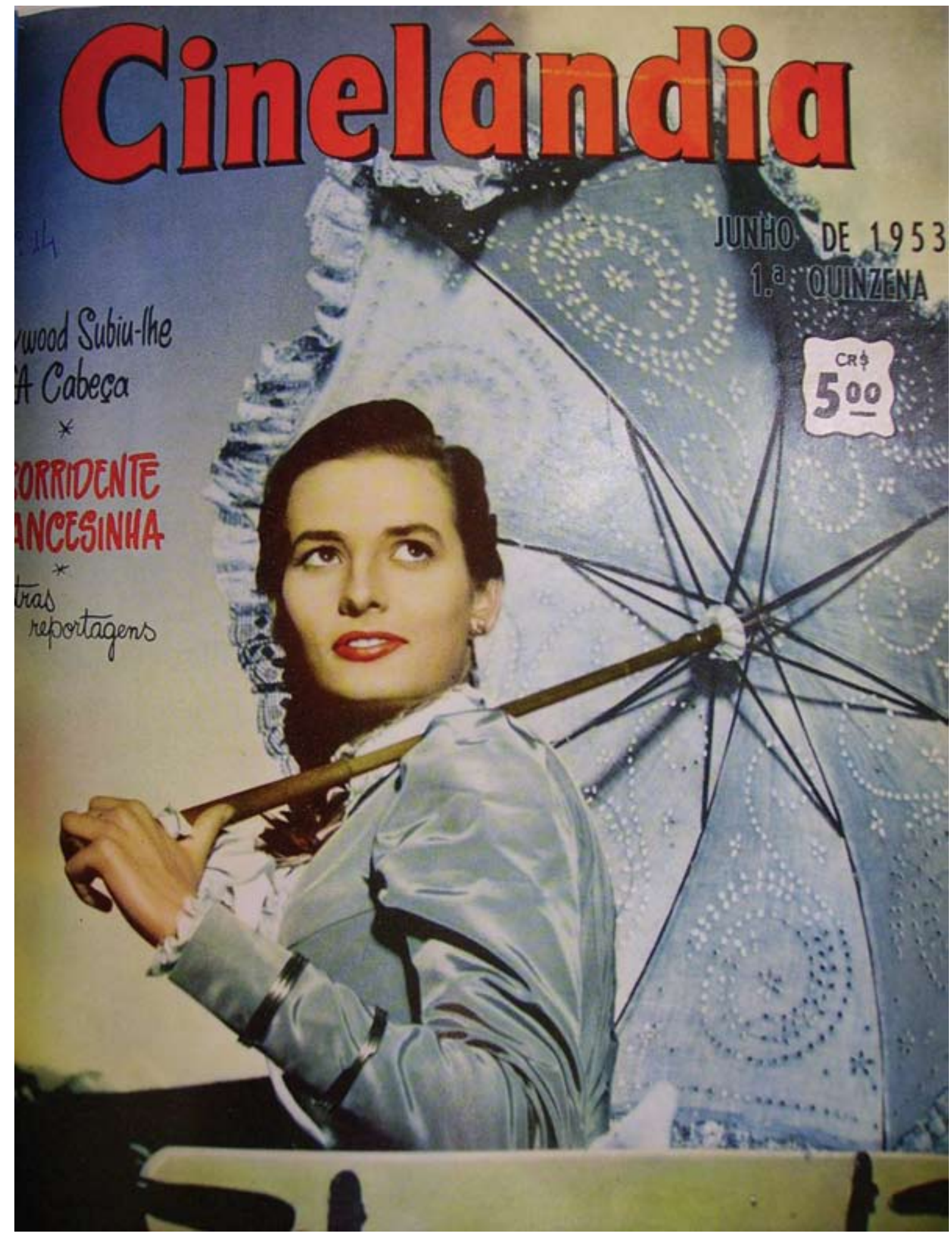

Figura 6 - Fotógrafo não identificado. Eliane Lage, em Sinhá Moça. Cinelândia, jun. 1953. Acervo da Biblioteca Jenny Klabin Segall, Museu Lasar Segall / IBRAM / MinC, São Paulo. 
47. Lina Bo Bardi permaneceu na direção da Habitat até 1954.

48. Não consegui encontrar informações precisas sobre a finalidade do cartaz polonês de Sinhá Moça. O original que consultei se encontra depositado na Bifi (Cinémathèque française, Paris); pode ser que seja um poster promocional da exibição comercial do filme na Polônia, pois os filmes da Vera Cruz tinham distribuição internacional (a de Sinhá Moça estava a cargo da Columbia Pictures).O autor do cartaz Roman Cieslewicz (Lviv, 1930 - Paris, 1996), estudou na Academia de Belas Artes da Cracóvia. Em 1963 transfere-se para Paris, onde trabalhou como diretor artístico das revistsa Elle e Vogue; em 1975 inicia uma parceria com o Centre Pompidou, produzindo vários pôsteres e cartazes. Dá aulas na Ecole Superieure d'arts Graphiques; em 1979, vence o Art Prin Grand Prix, o que lhe traz reconhecimento internacional. Disponível em: <http:// www.nouvellesimages.com/ Roman-Cieslewicz id artistes aut 404565 >; acesso em 29 abr. 2010; tradução livre da autora. Cieslewicz, em entrevista gravada no seu ateliê, em 16 jan. 1978, dizia sobre seu ofício: "Fiz mais de 400 pôsteres durante minha vida, mas não sei o que um artista de pôster significa, é isso. Um pôster é uma grande ideia, esse é o significado da coisa, basicamente, pois uma ideia pode excitar, pode in trigar, isso é muito importante". Disponível em: <http:// www.ina.fr/fresques/europe-des-cultures-en/notice/ Europe00086/roman-cieslewicz-poster-designer>; acesso em 29 abr. 2010; tradução livre da autora. descuido com nuances de cor, e Eliane surge num figurino casual, sem vinculação a nehuma personagem. Persiste apenas um elemento na composição dessa imagem, o olhar deslocado para o canto superior esquerdo, conferindo certa unidade às imagens da atriz, visto que é um posicionamento característico, presente em várias fotografias realizadas pelos estúdios.

Já a capa de Cinelândia remete às fotografias promocionais feitas pelo estúdio Vera Cruz, pois apresenta maior elaboração, revelando cuidado com o enquadramento e com a profundidade de campo. Na composição dessa imagem, temos em primeiríssimo plano o encosto da carruagem. Devidamente paramentada como a personagem Sinhá Moça, Eliane Lage segura uma sombrinha e volta-se para trás, numa posição de ligeira torção do tronco, causando assim sensação de movimento. A qualidade da imagem possibilita perceber a textura e as dobras do vestido. Tal elaboração remete ao material produzido pelos estúdios, cujo apuro estético extrapola as fotografias que funcionavam apenas para ilustrar reportagens.

Dentre o material concebido para ser publicado em revistas ou exposto em salas de cinema, temos os releases publicitários feitos a partir de fotogramas dos filmes (Figuras 7 a 1 1). Em tais fotografias, há uma valorização da cenografia e da iluminação, e uma sugestão da ação dramática, tentando "resumir" - por meio de apenas uma imagem - a essência do filme. Sendo assim, os fotógrafos lançam mão de recursos estilísticos, cenográficos e dramáticos. Dentre tais recursos, é notável perceber a utilização de espelhos que aprofundam o quadro, jogam com a cena, norteando o olhar de quem o mira e/ou desvendando quem nele se observa.

Ausências

Somando-se a frequente presença de Eliane Lage na imprensa, é igualmente interessante perceber sua ausência em algumas publicações. Bom exemplo disso é a revista Habitat - publicação do Museu de Arte de São Paulo e dirigida pela arquiteta Lina Bo Bardi -, que, ao comentar o filme Caiçara, jamais publicou uma imagem da atriz, mas sim da personagem coadjuvante, Sinhá Felicidade (loaquina Maria da Rocha), que causou grande alvoroço na estreia do filme, pois era uma catadora de papel lançada ao estrelato pela Vera Cruz (Figura 12). Ela foi considerada pela Habitat - provavelmente tentando escapar da "mesmice" da imprensa de grande circulação (que não dedicava espaço a uma atriz negra, humilde e sem atributos da beleza padrão) - como a "verdadeira revelação" da Vera Cruz ${ }^{47}$.

Nessa mesma linha da ausência da imagem de Eliane Lage temos o inspirado pôster do filme Sinhá Moça (figura 13), feito pelo artista polonês Roman Cieslewicz ${ }^{48}$. Considerado um dos maiores artistas gráficos da segunda metade do século XX, Cieslewicz - como imagem síntese do filme Sinhá Moça-desenhou a silhueta de uma mulher negra, vestida de branco, com a cabeça para voltada 


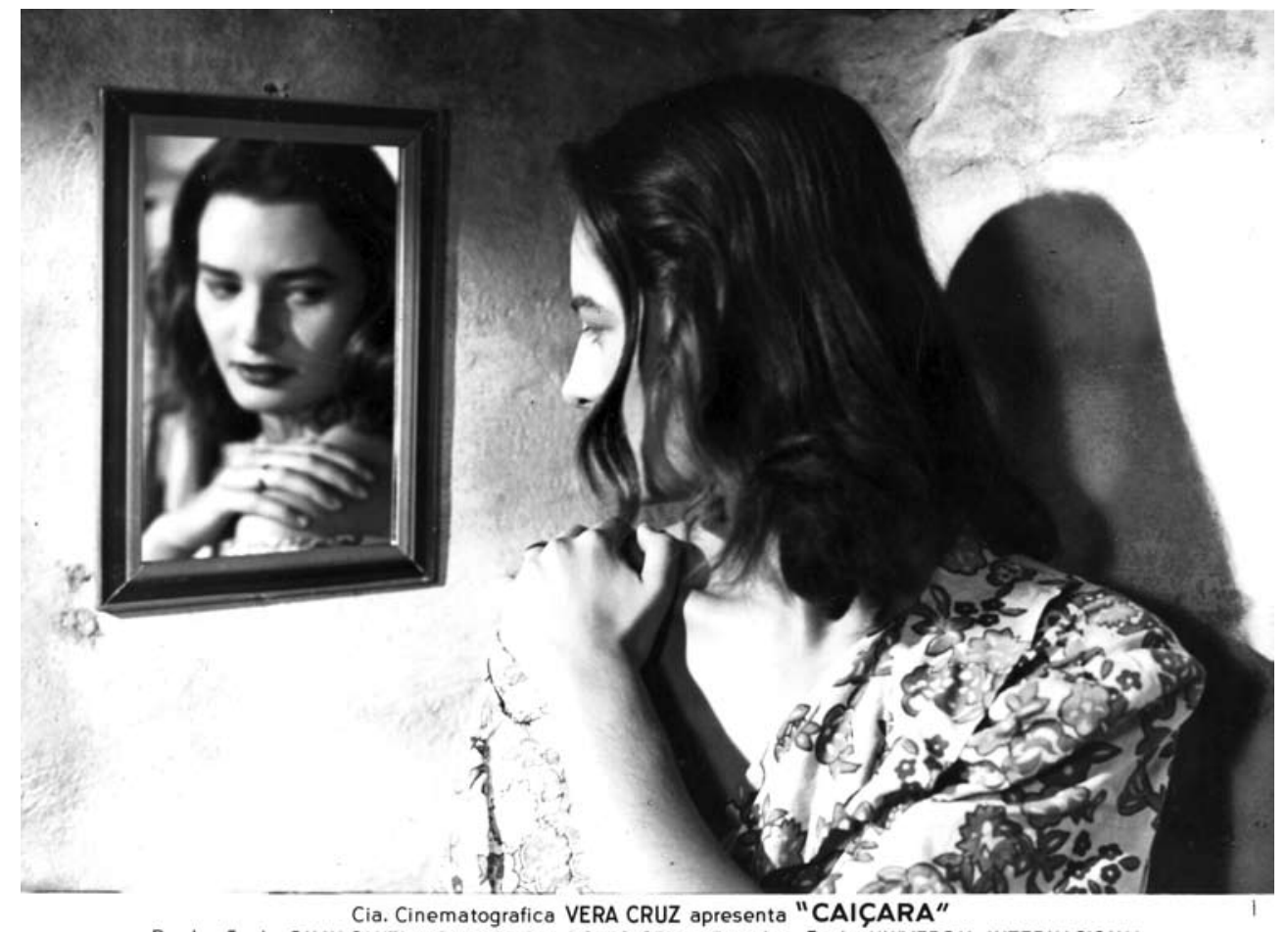

Produção de CAVALCANTI - Direção de ADOLFO CELI - Distribuição da UNIVERSAL INTERNACIONAL

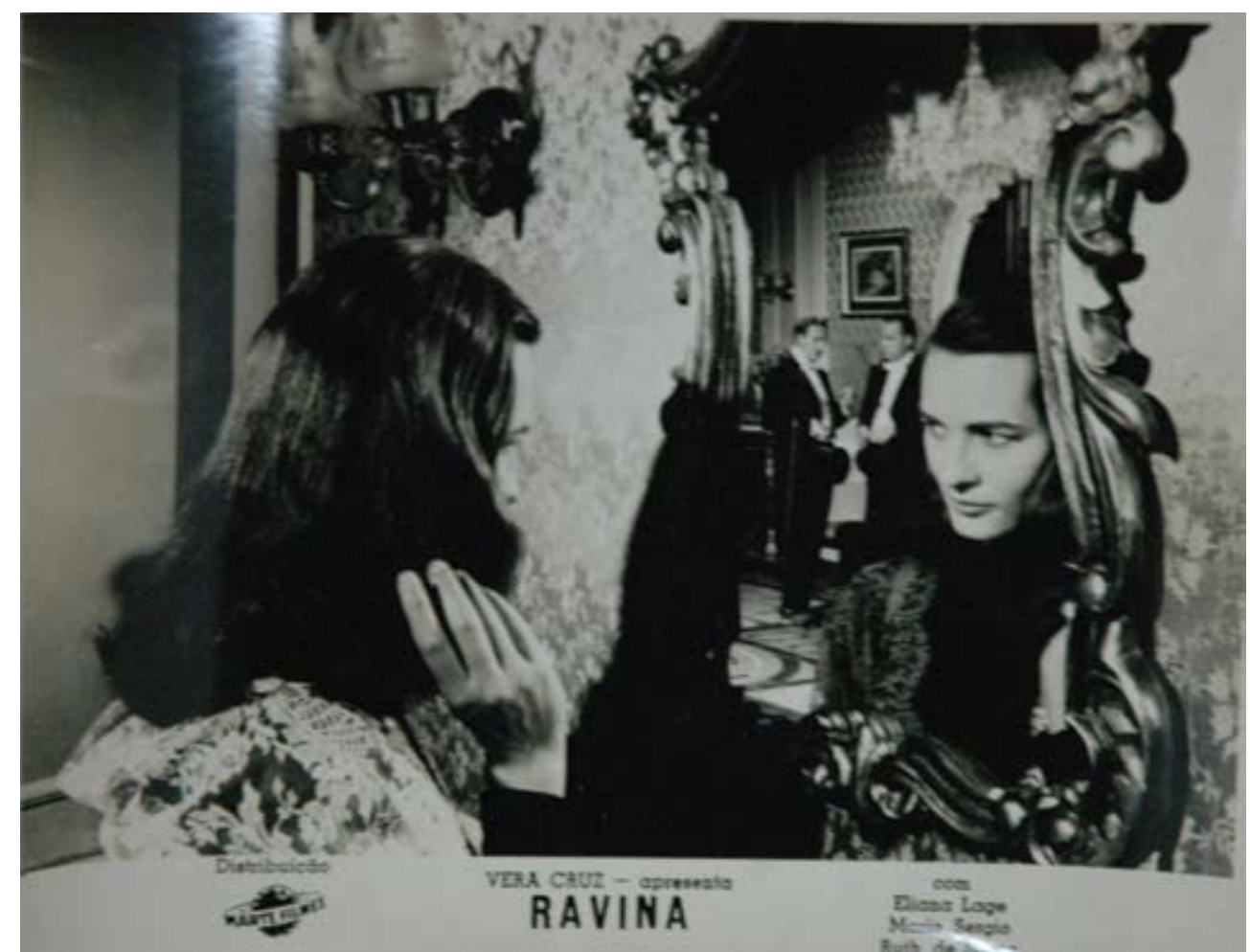

Figura 7 - Fotógrafo não identificado. Eliane Lage, em Caiçara. 1950. Acervo da Biblioteca Jenny Klabin Segall, Museu Lasar Segall / IBRAM / MinC, São Paulo.
Figura 8 - Fotógrafo não identificado. Eliane Lage, em Ravina. 1959. Acervo do Serviço de Patrimônio Histórico, Prefeitura de São Bernardo do Campo. 


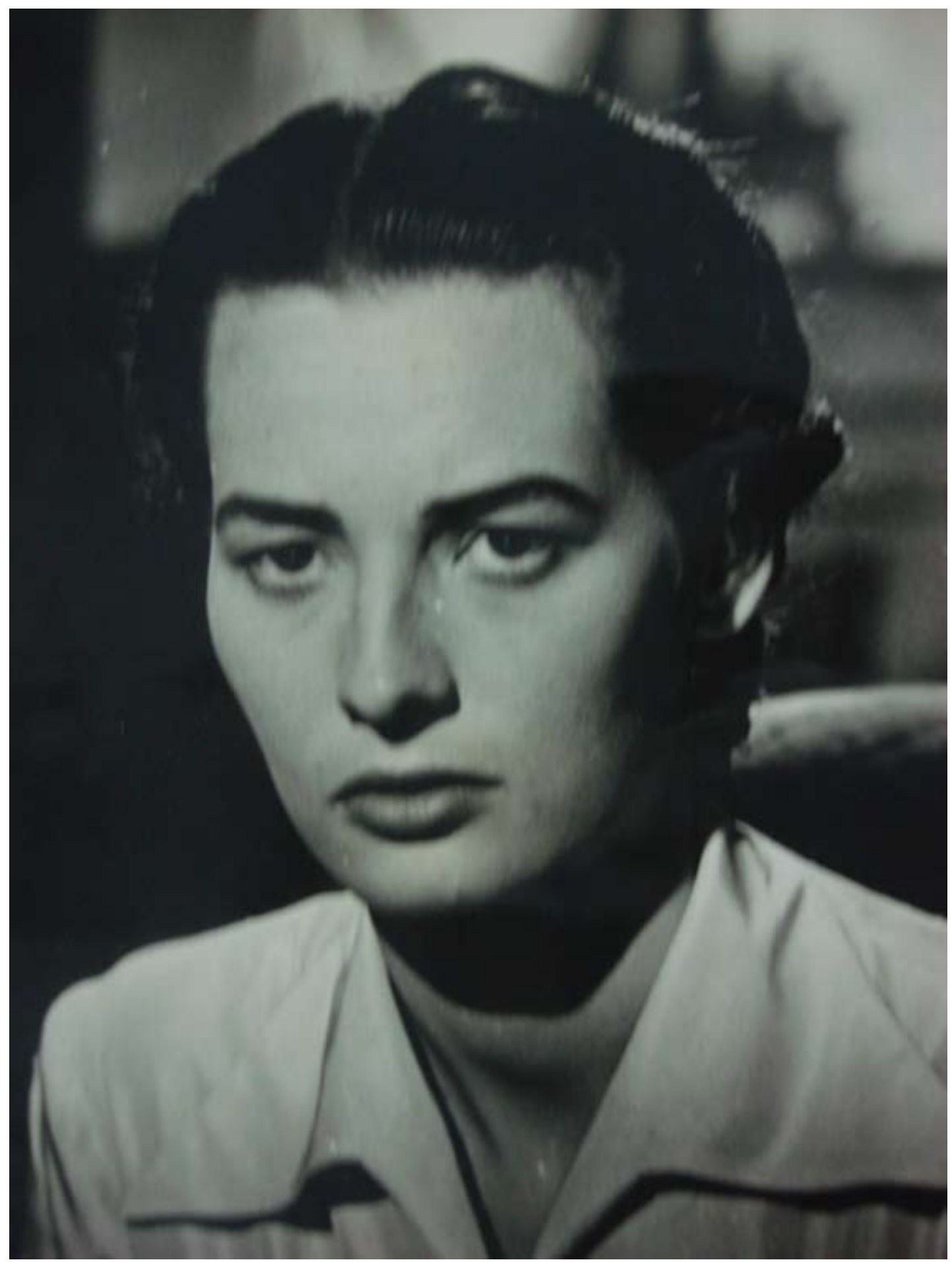

Figura 9 - Fotógrafo não identificado. Eliane Lage. Sem data. Acervo do Serviço de Patrimônio Histórico, Prefeitura de São Bernardo do Campo. 


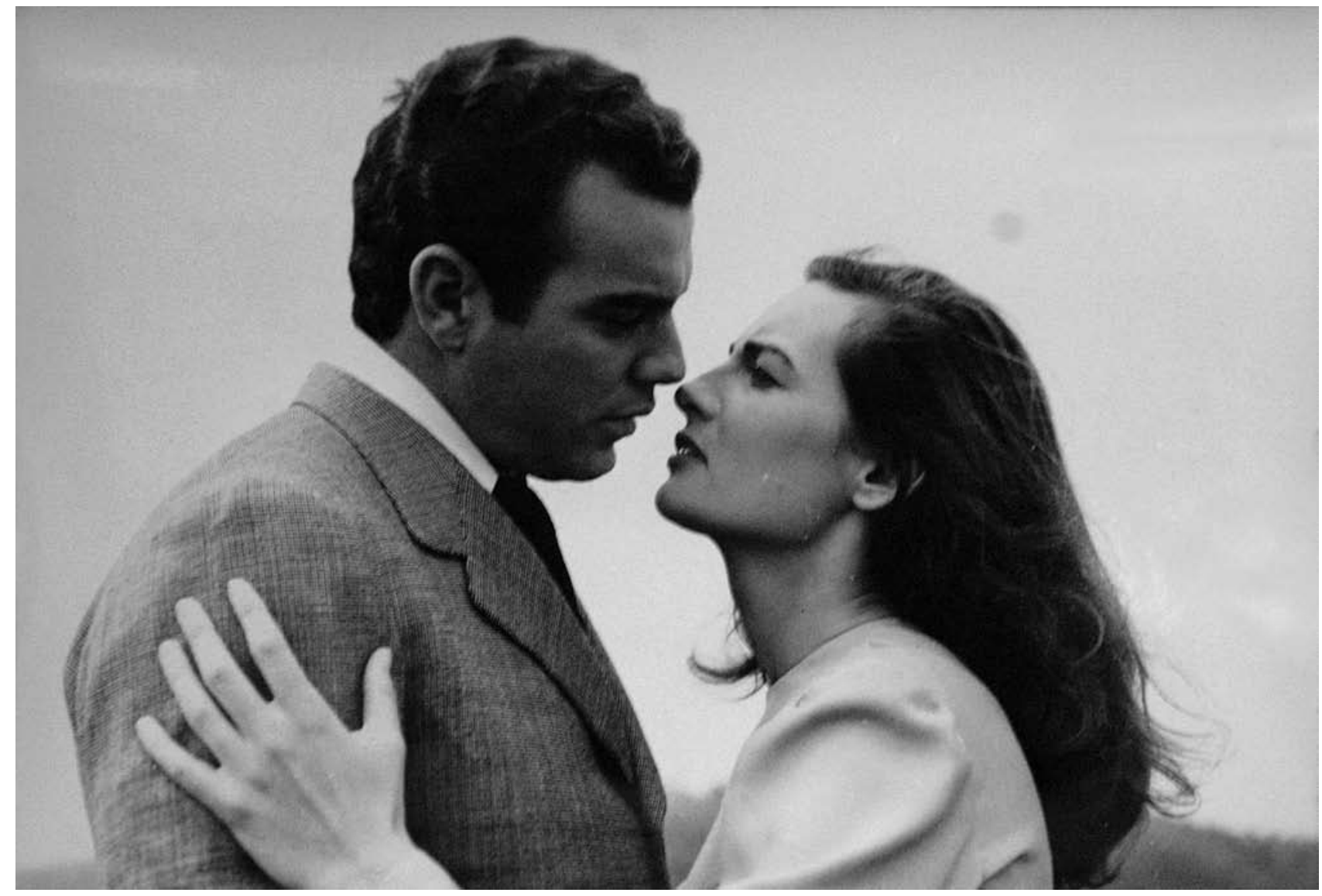

Figura 10 - Fotógrafo não identificado. Eliane Lage e Mário Sérgio, em Ravina. 1959. Acervo do Serviço de Patrimônio Histórico, Prefeitura de São Bernardo do Campo. 


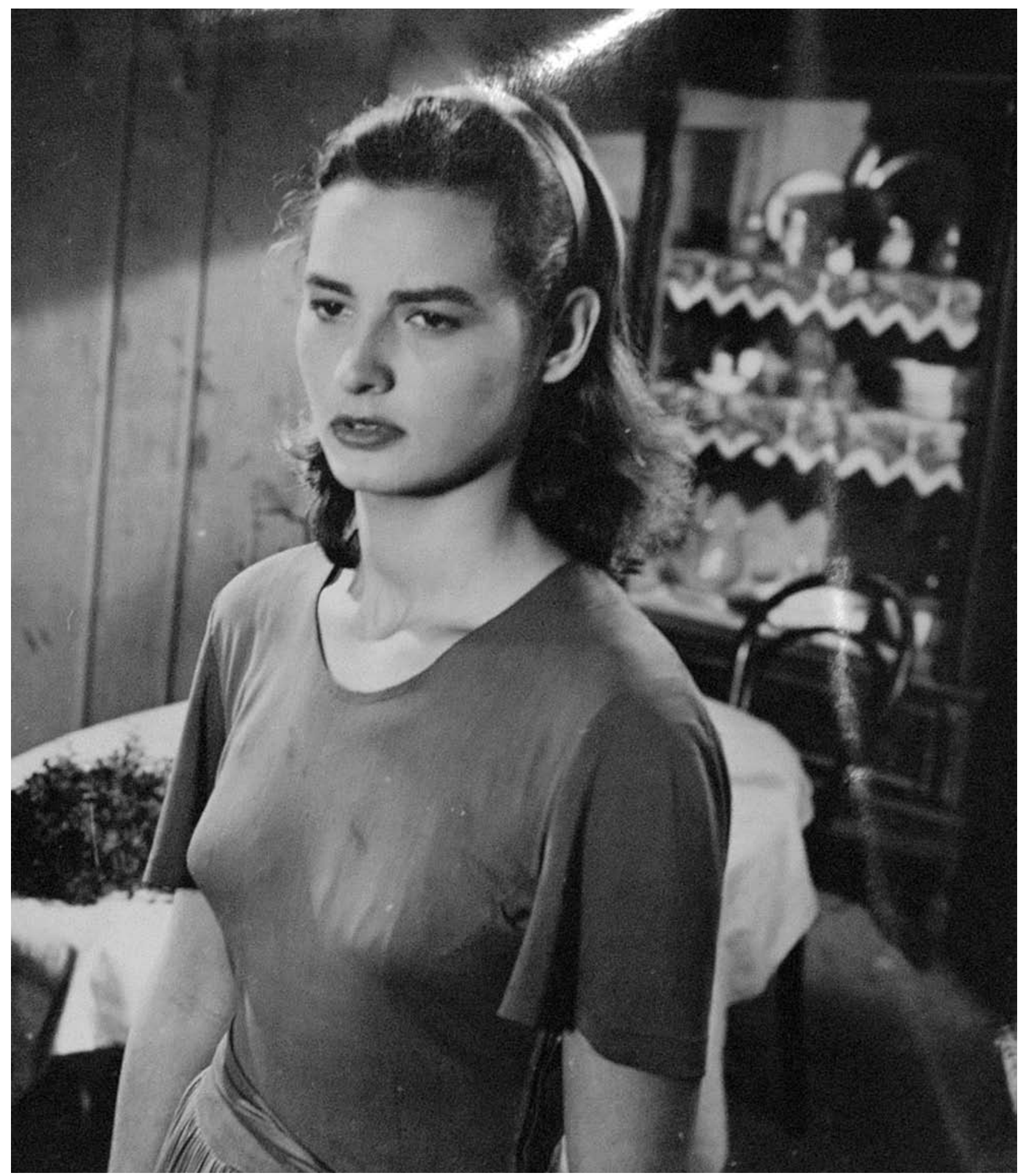

Figura 11 - Fotógrafo não identificado. Eliane Lage, em Caiçara. 1950. Acervo do Serviço de Patrimônio Histórico, Prefeitura de São Bernardo do Campo. 


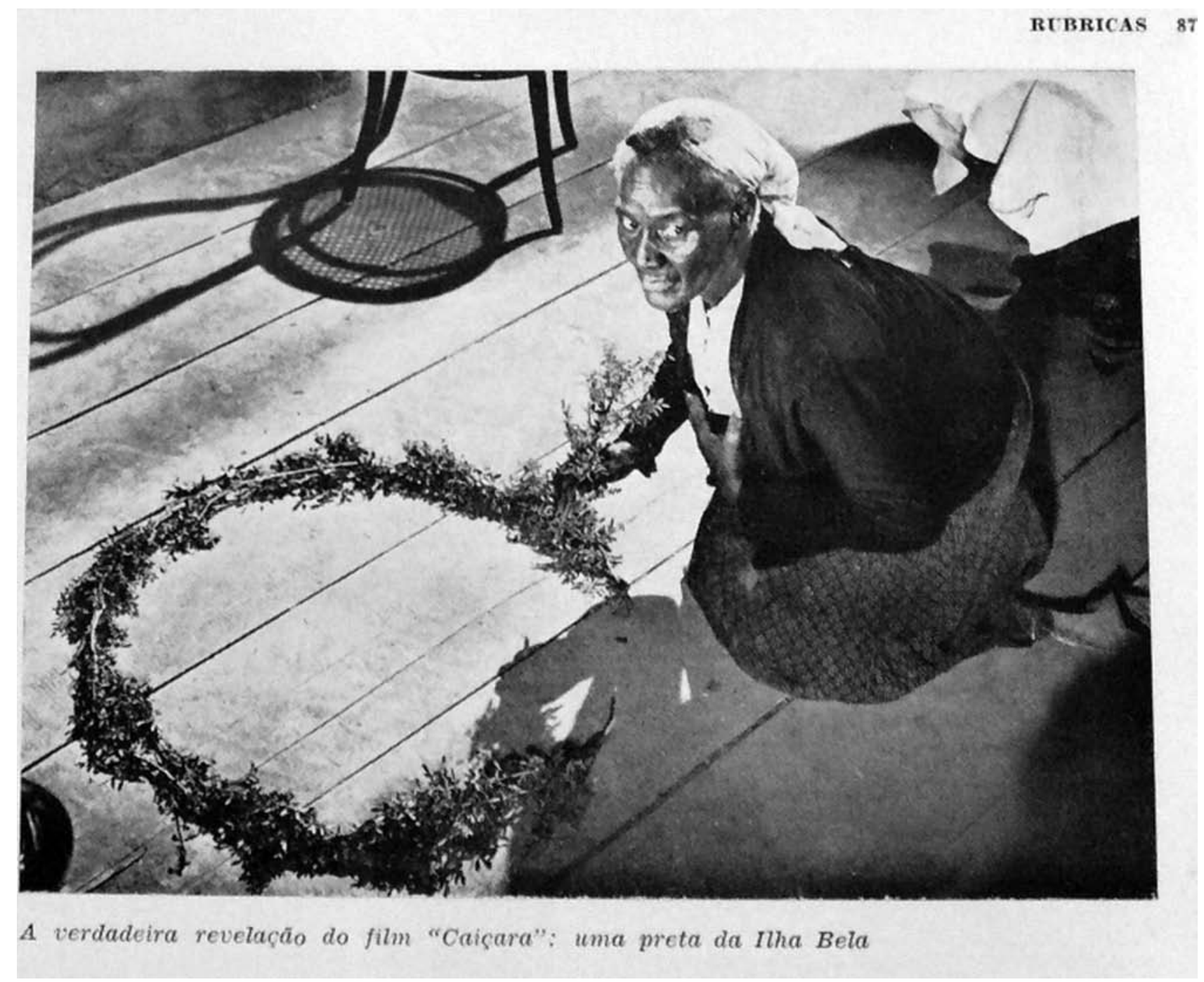

Figura 12 - Fotógrafo não identificado. Sinhá Felicidade, em Caiçara. 1950. Acervo do Museu de Arte de São Paulo, São Paulo. 


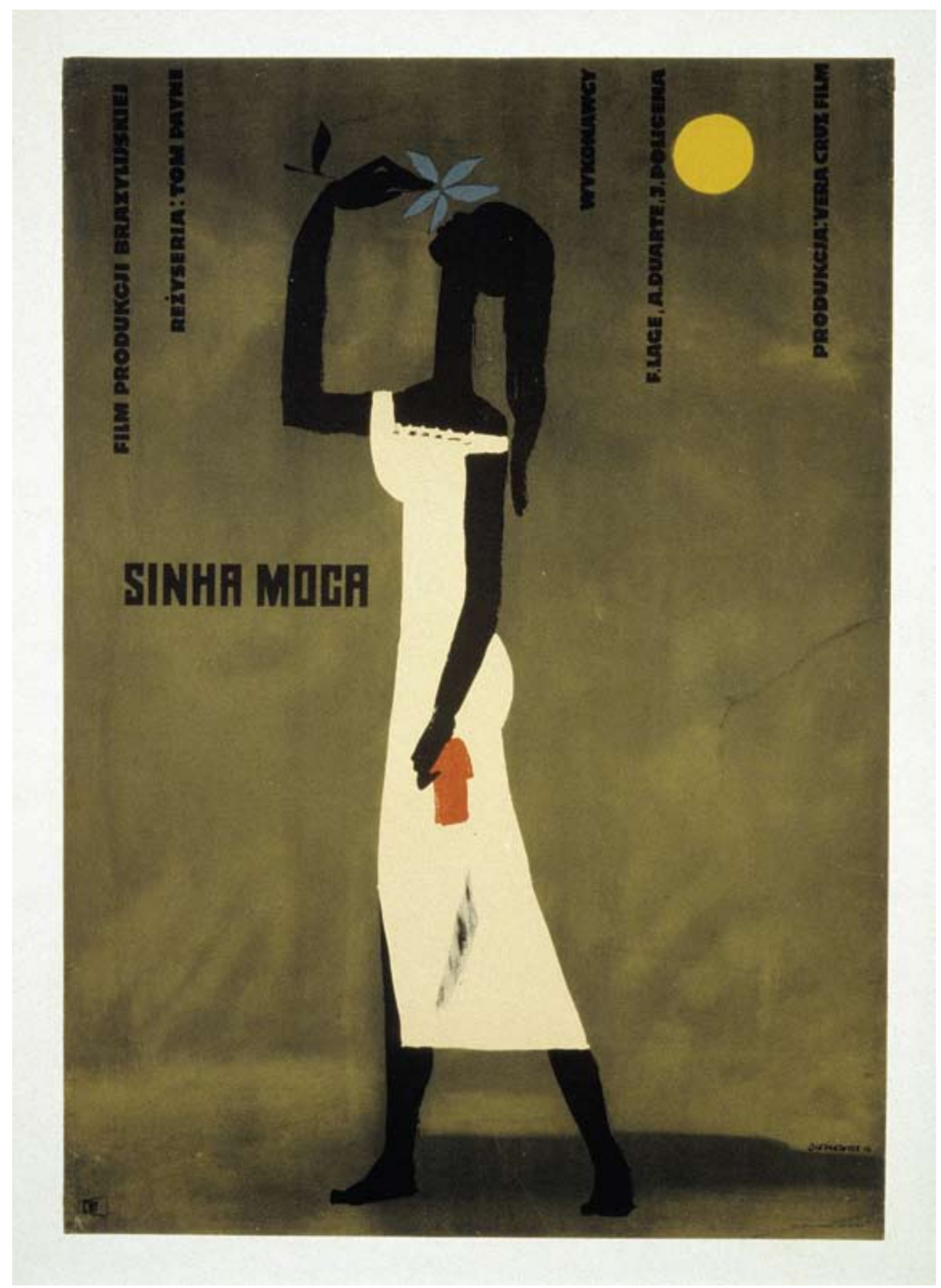

Figura 13 - Roman Cieslewicz. Cartaz de Sinhá Moça. Sem data. Fonte: Bifi, Cinemateca Francesa. 
o alto, cheirando uma flor azul. Na outra mão ela carrega uma espécie de lenço vermelho, uma representação que, ao abolir imagens óbvias, detém forte poder sugestivo. Há uma fotografia de divulgação de Sinhá Moça em que a atriz Ruth de Souza, no papel de escrava, caminha ao longe, trajando vestido branco (Figura 14). A semelhança entre a composição de Cieslewicz e a fotografia sugere a possibilidade de ter o gravurista nela se inspirado. Já o pôster brasileiro, remetendo aos filmes épicos norte-americanos, traz os protagonistas Eliane Lage e Anselmo Duarte em primeiro plano, tendo ao fundo um escravo acorrentado no pelourinho (Figura 15); iá o "cartazete" de divulgação da versão italiana de Sinhá Moça (La Dea Bianca) é um fotograma do filme (Figura 16).

Com o término da Vera Cruz, e depois de protagonizar seu último filme Ravina ${ }^{49}$, Eliane Lage foi paulatinamente desaparecendo da imprensa e da vida pública, pois, como ela afirmava repetidas vezes, fazer cinema a interessava desde que estivesse trabalhando junto com Tom Payne. Quando a Companhia fracassou,

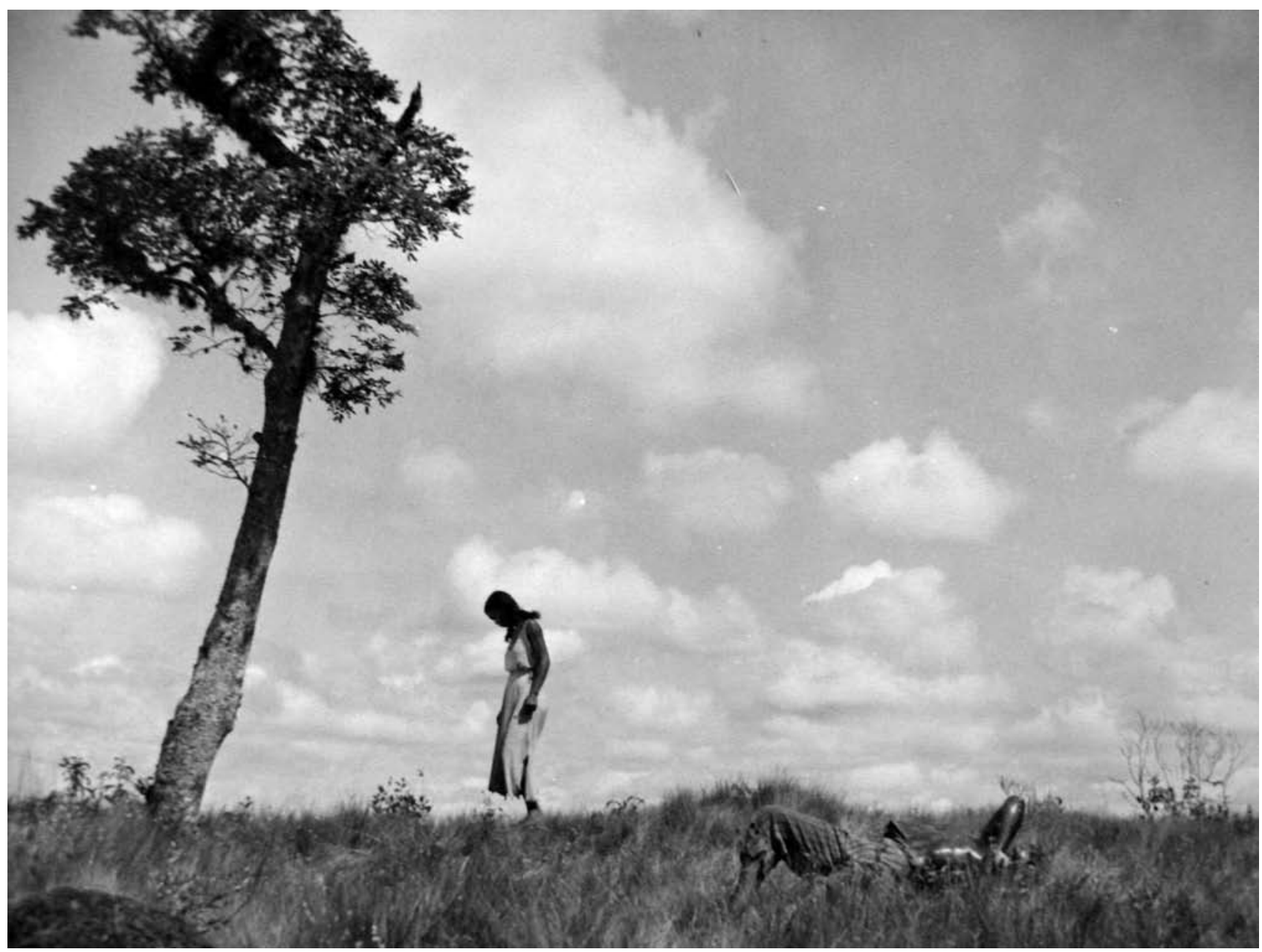

Figura 14 - Fotógrafo não identificado. Ruth de Souza, em Sinhá Moça. Sem data. Acervo do Serviço de Patrimônio Histórico, Prefeitura de São Bernardo do Campo. 


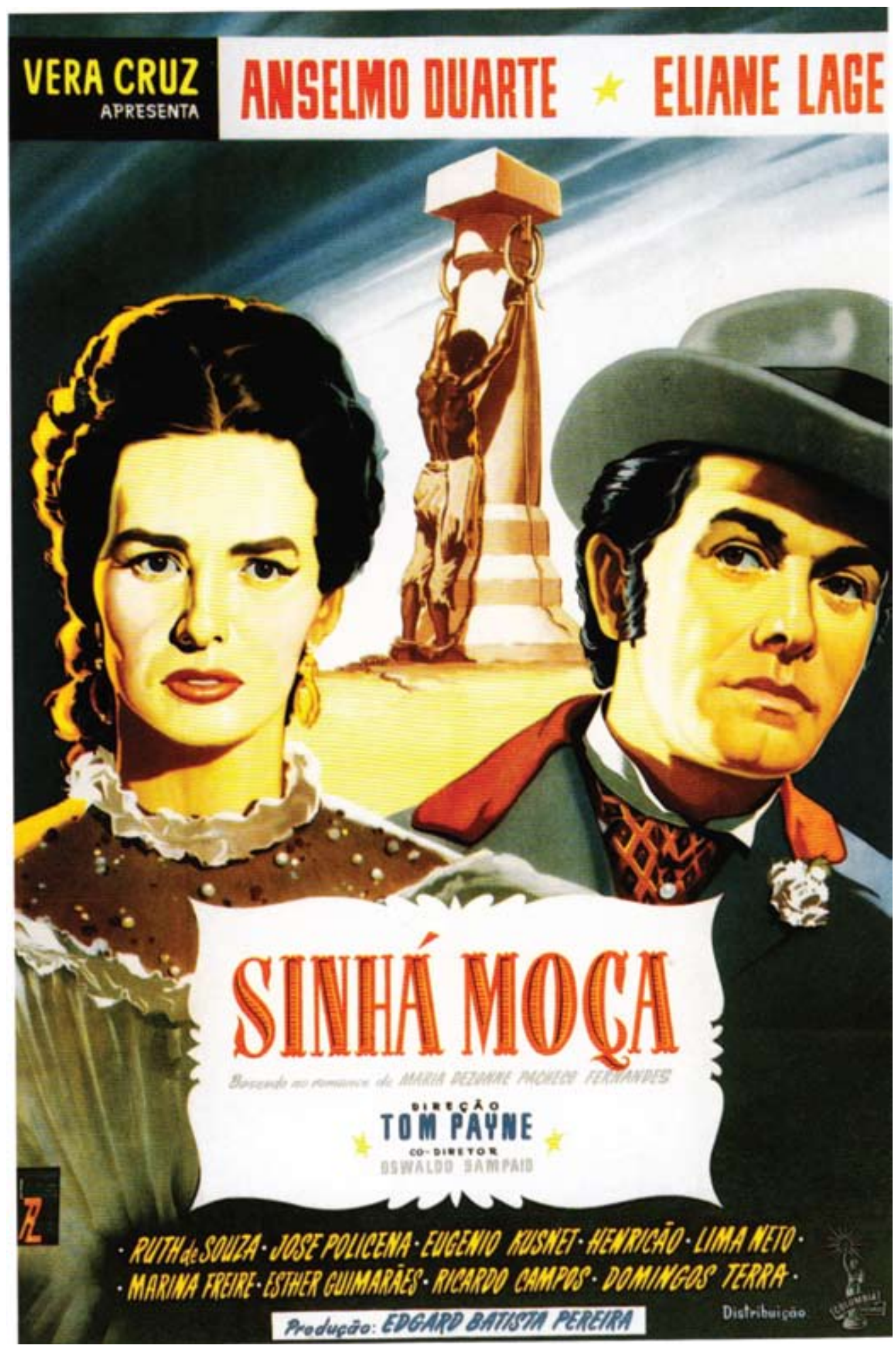

Figura 15 - Cartaz de Sinhá Moça. 1953. Fonte: Cinemateca 60 anos. São Paulo: Cinemateca Brasileira, 2006. 

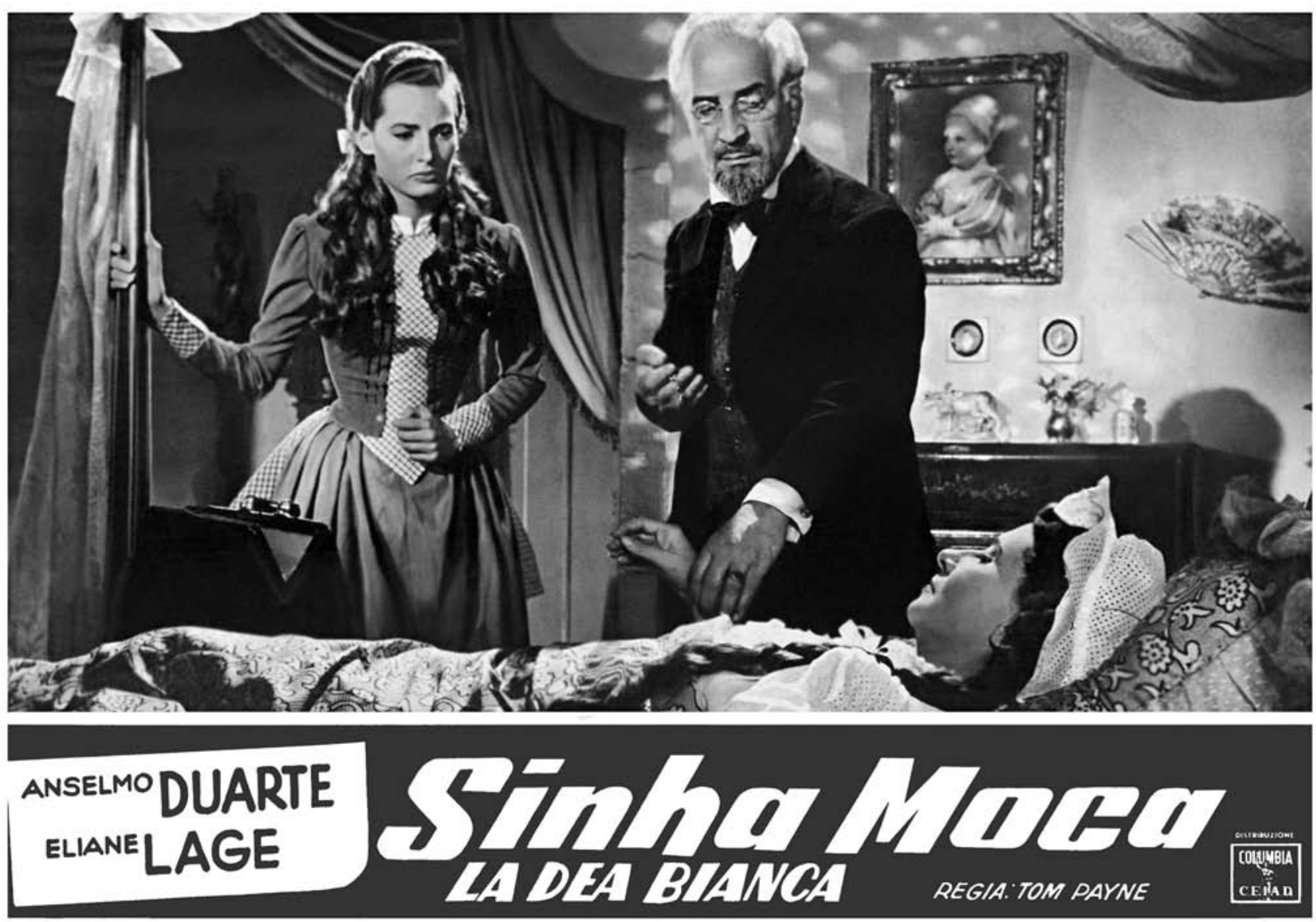

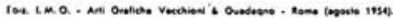

Figura 16 - Fotógrafo não identificado. Cartaz italiano de Sinhá Moça. Itália, 1954. Acervo pessoal de Marcelo Del Cima. 
50. Eliane (2002).

51. Não há uma bibliografia extensa dedicada especificamente à reflexão sobre o star system cinematográfico brasileiro. No que concerne às atrizes dos primórdios do século XX, gostaria de destacar a pesquisa de Ana Pessoa (2002) e de Heloisa Buarque de Hollanda (1991). Em artigo dedicado aos efeitos da política de boa vizinhança e suas consequências na vida cultural brasileira, a historiadora Ana Mauad analisa Carmem Miranda; ver Ana Mauad (2002). Dedicado ao star system brasileiro, perpassando desde o cinema mudo até a década de 1980 , há um artigo de Paulo Para-
Payne não conseguiu prosseguir trabalhando, sendo assim, pouco depois de finalizar Ravina, eles decidem ir morar no Guarujá. Em 1965, após a separação do casal, Eliane vai morar em Petrópolis, passa uma temporada em Olinda e, em 1977, muda-se para o interior de Goiás, onde passa a viver como fazendeira. Desde então, ela passou a figurar esporadicamente na imprensa, tendo sido tema do recente documentário Eliane (Figura 17) ${ }^{50}$.

Imagens de Eliane Lage ilustram uma época que teve começo, meio e fim, e cujo sistema de divulgação deixou de existir. A Vera Cruz sucumbiu e levou consigo o sonho de uma indústria de cinema no Brasil. As fotografias que selecionei e analisei ao longo do presente artigo são espectros, jogos de luzes e sombras, fragmentos. Este breve encadeamento, esta busca de similitudes e correlações, opera-se num material que não foi concebido para ser visto em conjunto e, talvez, não tenha obedecido a um claro propósito de representações. Se a indústria de cinema não vingou, isso tampouco ocorreu com o star system, que é fenômeno intimamente atrelado a economia cinematográfica ${ }^{51}$. Eliane Lage foi comparada aos grandes mitos do cinema, e evidências disso podem ser conferidas em poses, textos

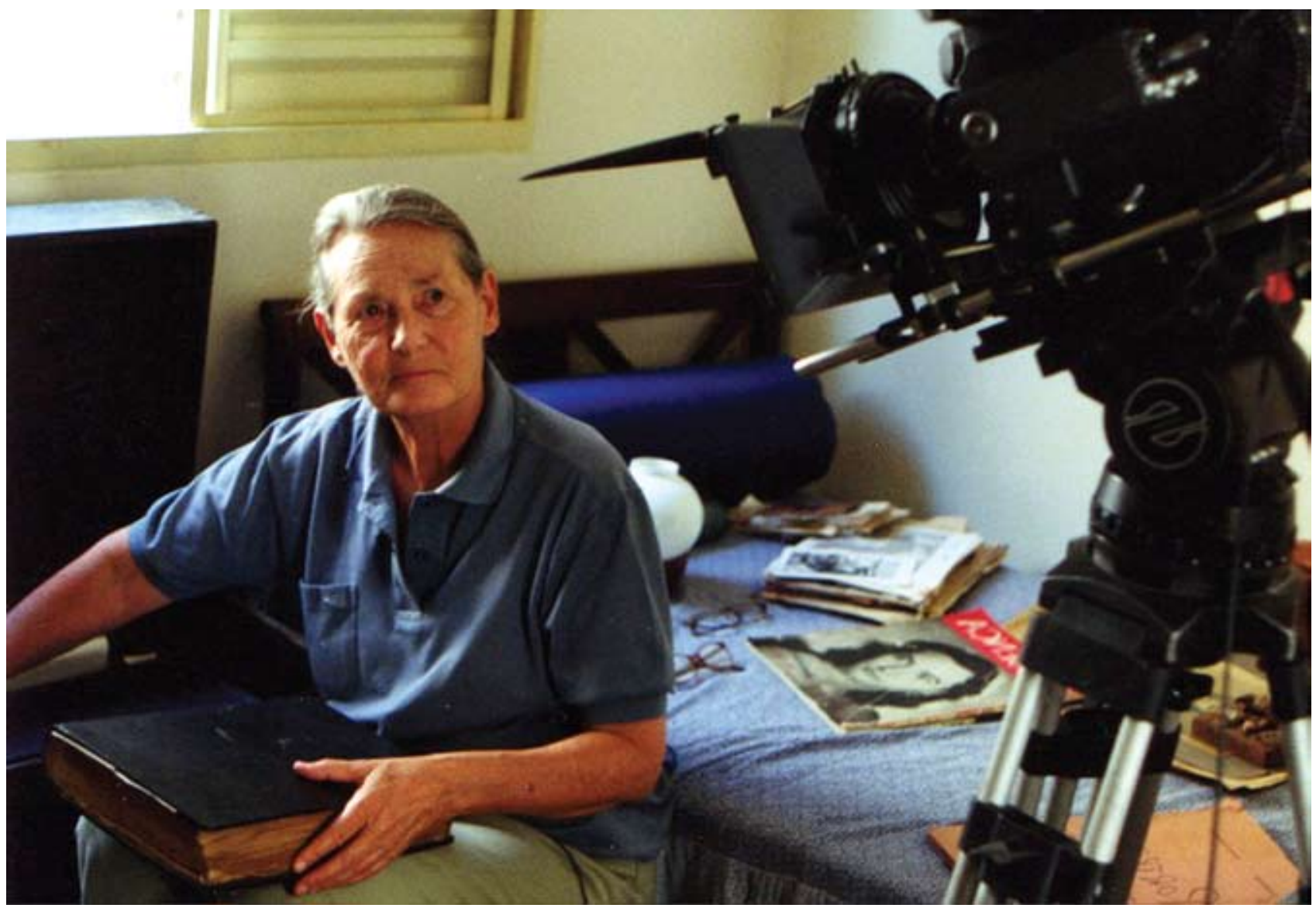

Figura 17 - Ana Carolina de M. D. Maciel. Eliane Lage, em fotografia de cena do documentário Eliane. 2001. Acervo pessoal da autora. 
ou depoimentos. Cumpre indagar: ela conseguiu ser um mito? Greta Garbo e Ingrid Bergman permaneceram no imaginário, mesmo sucessivamente substituídas por novas estrelas pois, segundo Barthes, existem "mitos muito antigos, mas não eternos 52 ". Imagem efêmera, Eliane Lage não teve um studio system que a amparasse por muito tempo. Atualmente suas fotografias são meros sinais, indícios que nos remetem diretamente à ausência, a passagem do tempo e aos sonhos fracassados.

\section{REFERÊNCIAS}

A. A. A Cinderela Brasileira. A Cena Muda, Rio de Janeiro, , 29 ago. 1950.

A CENA Muda, Rio de Janeiro, 20 ago. 1951.

Rio de Janeiro, 5 set. 1952.

AUMONT, Jacques. El rostro en el cine. Barcelona: Paidós, 1992.

; MARIE, Michel. Dicionário teórico e critico de cinema. Trad. Eloisa Araújo Ribeiro. Campinas: Papirus, 2007.

BARTHES, Roland. Mitologias. 9. ed. Trad. Rita Buongermino; Pedro de Souza. Rio de Janeiro: Bertrand Brasil, 1993.

CAPA. Foco, São Paulo, v. 1, n. 2, jul. 1951.

CHARNEY, Leo; SCHWARTZ, Vanessa R. (Org.). O Cinema e a invenção da vida moderna. Trad. Regina Thompson. São Paulo: Cosac \& Naify, 2001.

CINELÂNDIA, Rio de Janeiro, , v. 1, 1-15 jul. 1953a.

Rio de Janeiro, v. 1, 16-31 jul. 1953b.

Rio de Janeiro, v. 2, 1-15 fev. 1954a.

Rio de Janeiro, v. 2, 1-15 maio 1954b.

Rio de Janeiro, v. 11, n. 248, p. 60, mar. 1963.

GONÇALVES FILHO, Antonio. Fantasias de um visionário [entrevista com Robert Wilson]. $O$ Estado de S. Paulo, São Paulo, 25 nov. 2008.

GUNNING, Tom. O retrato do corpo humano: a fotografia, os detetives e os primórdios do cinema. In: CHARNEY, Leo; SCHWARTZ, Vanessa R. (Org.). O cinema e a invenção da vida moderna. Trad. Regina Thompson. São Paulo: Cosac \& Naify, 2001. p. 39-80

HOLLANDA, Heloisa Buarque de. Quase catálogo. Estrelas do cinema mudo Brasil 1908-1930. Rio de Janeiro: Ciec; Escola de Comunicação da UFRJ, 1991.

KRACAUER, Siegfried. A fotografia. In: O ornamento da massa: ensaios. Trad. Carlos Eduardo Jordão Machado; Marlene Holzhausen. São Paulo: Cosac \& Naify, 2009. p.63-80. naguá ([s. d.]). Especificamente sobre os anos 1950 , há minha tese de doutoramento; ver Ana Carolina de M. D. Maciel (2008); o capítulo que escrevi sobre Eliane Lage; ver Ana Carolina de M D. Maciel (2009a); e um artigo intitulado Eliane Lage e a Vera Cruz: nasce uma estrela; ver Ana Carolina de M. D. Maciel (2009b). Esse breve levantamento não intenta esgotar todos os trabalhos realizados sobre o tema.

52. Cf.Roland Barthes (1993, p. 132). 
MALRAUX, André. Esquisse d'une Psychologie du Cinéma. Paris: Gallimard, 1946.

MORIN, Edgar. O Cinema ou o bomem imaginário: ensaio de antropologia. Trad. AntónioPedro Vasconcelos. Lisboa: Relógio d'Água, 1999.

Meus Demônios. 2. ed. Trad. Leneide Duarte; Clarisse Meireles. Rio de Janeiro: Bertrand Brasil, 2000.

MACIEL, Ana Carolina de M. D. "Yes, nós temos bananas". Cinema industrial paulista: a companhia cinematográfica Vera Cruz, atrizes de cinema e Eliane Lage. 2008. Tese (Doutorado em História) - Departamento de História, Universidade Estadual de Campinas, 2008.

Eliane Lage: imagem e imaginário. In: CORSEUIL, Anelise Reich et. al. Cinema, lanterna mágica da bistória e da mitologia. Florianópolis: Editora da UFSC, 2009a. p. 187-209

Eliane Lage e a Vera Cruz: nasce uma estrela. In: INSTITUTO MOREIRA SALLES. Programa de cinema., São Paulo, nov. 2009b.

MAUAD, Ana Maria. As três Américas de Carmem Miranda: cultura política e cinema no contexto da política da Boa Vizinhança. Transit Circle, Rio de Janeiro, v.1, p. 52-77, 2002.

PARANAGUÁ, Paulo. Brasil: Star System y Medios de Comunicacion de Masas. Mimeo. [s. d.].

PESSOA, Ana. Carmen Santos. Rio de Janeiro: Aeroplano, 2002.

PONTES, Heloisa. Intérpretes da Metrópole: história social e relações de gênero no teatro e no campo intelectual brasileiro. São Paulo: Edusp, [n. p.].

XAVIER, Ismail (Org.). A Experiência do Cinema. Rio de Janeiro: Graal, 1991.

FILMES

ÂNGELA. Direção: Abílio Pereira de Almeida e Tom Payne. Produção: Abílio Pereira de Almeida. Intérpretes: Eliane Lage, Alberto Ruschel, Mário Sérgio, Abílio Pereira de Almeida, Inezita Barroso, Ruth de Souza, Luciano Salce, Maria Clara Machado e outros. Roteiro: Alberto Cavalcanti, Neri Dutra e Aníbal Machado. Produtora: Companhia Cinematográfica Vera Cruz, 1951, (92 min.), son., P\&B, 35mm.

APASSIONATA. Direção: Fernando de Barros. Produção: Renato Consorte. Intérpretes: Tônia Carrero, Anselmo Duarte, Alberto Ruschel, Ziembinsky, Abílio Pereira de Almeida, Paulo Autran e outros. Roteiro: Agostinho Santos Pereira. Companhia Cinematográfica Vera Cruz, 1952 (102 min.), P\&B, $35 \mathrm{~mm}$.

CAIÇARA. Direção: Adolfo Celi. Produção: Alberto Cavalcanti. Intérpretes: Eliane Lage, Abílio Pereira de Almeida, Carlos Vergueiro, Mário Sérgio, Maria Joaquina da Rocha e outros. Roteiro: Alberto Cavalcanti e Adolfo Celi. Produtora: Companhia Cinematográfica Vera Cruz, 1950, (92 min)., son., P\&B, $35 \mathrm{~mm}$.

É PROIBIDO beijar. Direção: Ugo Lombardi. Intérpretes: Tônia Carrero, Mario Sérgio, Ziembinski, Otelo Zeloni, Inezita Barroso, Renato Consorte e outros. Roteiro: Fábio Carpi e Mauricio Vasquez. Produtora: Companhia Cinematográfica Vera Cruz, 1953, (80 min.), P\&B, son., 35mm. 
ELIANE. Direção: Ana Carolina Maciel e Caco Souza. Roteiro: Ana Carolina Maciel. Produtora: Viralata Filmes. 2002 (33 min), cor, son. 16mm.

RAVINA. Direção: Rubem Biafora. Intérpretes: Eliane Lage, Mário Sérgio, Sérgio hINGST, Pedro Paulo Hatheyer, Ruth de Souza e outros. Roteiro: Rubem Biáfora e Walter Guimarães Mota. Produtora: Brasil Filmes, 1958, (117 min.), son., P\&B, 35mm.

SINHÁ MOÇA. Direção: Tom Payne e Osvaldo Sampaio. Produção: Edgar Batista Pereira. Intérpretes: Eliane Lage, Anselmo Duarte, José Policena, Ruth de Souza, Eugênio Kusnet, Marina Freire, Abílio Pereira de Almeida, Renato Consorte e outros. Roteiro: Maria Dezzone Pacheco Fernandes, Tom Payne e Osvaldo Sampaio. Produtora: Companhia Cinematográfica Vera Cruz, 1952 (110 min.), son. P\&B, 35mm.

STROMBOLI. . Direção: Roberto Rosselini. Intérpretes: Ingrid Bergman, Mario Vitale, Renzo Cesana, Mario Sponzo e outros. Roteiro: Roberto Rosselini; 1950 (107 min), son., P\&B, 35 mm

TICO TICO no Fubá. Direção: Adolfo Celi. Intérpretes: Anselmo Duarte, Tônia Carrero, Marisa Prado, Marina Freire, Ziembinski, Modesto de Souza, Piolin, Lima Barreto e outros. Roteiro: Osvaldo Sampaio. Produtora: Companhia Cinematográfica Vera Cruz, 1952, (109 min.), P\&B, son. $35 \mathrm{~mm}$.

SITES

$<$ http://www.bifi.fr>.

$<$ http://www.iconica.com.br>.

$<$ http://www.nouvellesimages.com>.

$<$ http://www.doctormacro.com $>$.

$<$ http://upload.wikimedia.org $>$. 